\title{
30 YEARS OF THE MINERALOCORTICOID RECEPTOR The brain mineralocorticoid receptor: a saga in three episodes
}

\author{
Marian Joëls ${ }^{1,2}$ and E Ronald de Kloet ${ }^{3}$ \\ 1Department of Translational Neuroscience, Brain Center Rudolf Magnus, University Medical Center, \\ Utrecht, The Netherlands \\ 2University of Groningen, University Medical Center, Groningen, The Netherlands \\ 3Division of Endocrinology, Department of Internal Medicine, Leiden University Medical Center, \\ Leiden, The Netherlands
}

Correspondence

should be addressed

to $E$ R de Kloet

Email

e.kloet@lacdr.leidenuniv.nl

\begin{abstract}
In 1968, Bruce McEwen discovered that ${ }^{3} \mathrm{H}$-corticosterone administered to adrenalectomised rats is retained in neurons of hippocampus rather than those of hypothalamus. This discovery signalled the expansion of endocrinology into the science of higher brain regions. With this in mind, our contribution highlights the saga of the brain mineralocorticoid receptor (MR) in three episodes. First, the precloning era dominated by the conundrum of two types of corticosterone-binding receptors in the brain, which led to the identification of the high-affinity corticosterone receptor as the 'promiscuous' MR cloned in 1987 by Jeff Arriza and Ron Evans in addition to the classical glucocorticoid receptor (GR). Then, the post-cloning period aimed to disentangle the function of the brain MR from that of the closely related GR on different levels of biological complexity. Finally, the synthesis section that highlights the two faces of brain MR: Salt and Stress. 'Salt' refers to the regulation of salt appetite, and reciprocal arousal, motivation and reward, by a network of aldosterone-selective MR-expressing neurons projecting from nucleus tractus solitarii (NTS) and circumventricular organs. 'Stress' is about the limbic-forebrain nuclear and membrane MRs, which act as a switch in the selection of the best response to cope with a stressor. For this purpose, activation of the limbic MR promotes selective attention, memory retrieval and the appraisal process, while driving emotional expressions of fear and aggression. Subsequently, rising glucocorticoid concentrations activate GRs in limbic-forebrain circuitry underlying executive functions and memory storage, which contribute in balance with MR-mediated actions to homeostasis, excitability and behavioural adaptation.
\end{abstract}

Key Words
- brain

- stress

- behavioural adaptation

- neuronal circuits

- mineralocorticoid receptors

- glucocorticoid receptors

\section{Introduction}

On Tuesday April 14, 1987, while visiting Ron Evans and Jeff Arriza, we learned that they had cloned the mineralocorticoid receptor (NR3C2 or MR). At the time, one of us (M Joëls) was working next door, with George Siggins and Floyd Bloom at the Scripps Clinic. Evans' and Arriza's manuscript had just passed the Science review process and was waiting to be published on July 6 th of the same year (Arriza et al. 1987). We were all excited, particularly as from our studies, evidence was mounting that there had to be an MR-like receptor 
co-existing with the classical glucocorticoid receptors (GRs) in the brain. This was discovered in seminal binding studies using ${ }^{3} \mathrm{H}$-corticosterone in the absence or presence of the unlabeled pure glucocorticoid RU28362 (Moguilewsky \& Raynaud 1980). The San Diego visit in March 1987 gave us (E R de Kloet) a head start in combining new methods to measure MR with the knowledge gained from pharmacological and endocrine studies.

In this tribute to the 30 years anniversary of the cloning of the MR, we will try to capture the special feeling that MR scientists of this world share. This is because many card-carrying MR aficionados are old enough to remember the attempts to piece together what the peculiar aldosterone- and corticosterone receptor-binding profiles meant and still young enough to appreciate the technological breakthroughs for the sake of better MR understanding. Here, we will start with a brief account of the pre-MR cloning era, then highlight the excitement during the first 5 post-cloning years and conclude with a synthesis that is beginning to reveal the plot of an unfolding brain MR story.

\section{Precloning era}

When Bruce McEwen at Rockefeller University inspected the print out of the scintillation counter to learn about brain retention and uptake of ${ }^{3} \mathrm{H}$-corticosterone administered to an adrenalectomised (ADX) rat, he was shocked. Wisdom at the time predicted that the hormone would accumulate in the 'hypophysiotropic' hypothalamus that harboured the main regulator of the hypothalamic-pituitary-adrenal (HPA) axis: corticotropinreleasing hormone (CRH, cloned in 1981 by the late Wylie Vale) and vasopressin in the paraventricular nucleus (PVN). However, it was not in the PVN that corticosterone was retained; by far the highest uptake and retention of the tracer occurred in the hippocampus (McEwen et al. 1968, Gerlach \& McEwen 1972). This observation matched with the behavioural and neuroendocrine effects of glucocorticoid implants in suprahypothalamic regions (Bohus \& Lissak 1968). The impact was large: it became clear that brain regions beyond the hypothalamus had to be of crucial importance for the action of adrenal hormones on the processing of salient information (McEwen et al. 2015).

Tracer amounts of corticosterone are retained and accumulated by mineralocorticoid receptors in extrahypothalamic limbic brain regions.
Saturday November 30, 1968, the Nature publication on hippocampal corticosterone retention was published, and Monday December 2, I (E R de Kloet) started my $\mathrm{PhD}$ research. In those days, there was no distracting Internet. New research findings were read and discussed immediately after publication. Inspired by the new data, one could do right away a cutting-edge experiment in a Popperian attempt to reject a hypothesis as there were no time-consuming rules and regulations. For instance, in this corticosterone case, we assumed in The Netherlands that we would get better results with the much more potent synthetic glucocorticoid dexamethasone. However, whatever I (E R de Kloet) tried, dexamethasone did not mimic corticosterone binding in the rat brain but, rather, was retained in the pituitary (de Kloet et al. 1974). In 1975, when I (E R de Kloet) was a postdoc in Bruce McEwen's lab, it was concluded that the ${ }^{3} \mathrm{H}$-dexamethasone tracer was indeed poorly retained in cell nuclei of hippocampus (de Kloet et al. 1975). About 20 years later, we discovered one of the two reasons: in contrast to corticosterone, the dexamethasone tracer poorly penetrates the brain because it is a substrate for multidrug resistance P-glycoproteins ( $\mathrm{mdr}$ Pgp) encoded by the $A B C B 1$ gene in the blood-brain barrier (Meijer et al. 1998).

The other reason was that if ${ }^{3} \mathrm{H}$-dexamethasone had been able to penetrate the brain, the receptor binding in the hippocampus would still have differed from that reported by McEwen for ${ }^{3} \mathrm{H}$-corticosterone. Even in the mid-seventies, we were already entertaining this idea, i.e., the existence of two distinct populations of receptor sites for corticosterone and dexamethasone (de Kloet et al. 1975, McEwen et al. 1976). Meanwhile, ${ }^{3} \mathrm{H}$-aldosterone autoradiography and cytosol receptor binding showed a striking similarity with the pattern of corticosterone retention in the rat brain (Ermisch \& Rühle 1978, de Nicola et al. 1981, Beaumont \& Fanestil 1983). Moreover, inclusion of the glucocorticoid RU28362 appeared to discriminate between high- and low-affinity binding of corticosterone (Moguilewsky \& Raynaud 1980, Veldhuis et al. 1982). Then, it was discovered by the late Zig Krozowski that cytosol of brain and kidney display similar binding properties for aldosterone, the certified mineralocorticoid (Krozowski \& Funder 1983). Finally, the hippocampal cells expressing irGR (Fuxe et al. 1985) did not match the autoradiograms of the naturally occurring corticosterone (Gerlach \& McEwen 1972). Notably, the hippocampal CA3 virtually lacked GR, whereas the very same area was known to

Published by Bioscientifica Ltd 
highly retain tracer amounts of ${ }^{3} \mathrm{H}$-corticosterone in adrenalectomised rats.

That was the moment the idea sparked that we probably missed the GR in the autoradiograms because its affinity was too low to produce a signal after the tracer doses of ${ }^{3} \mathrm{H}$-corticosterone. Thus, we administered in vivo graded doses of corticosterone to adrenalectomised animals, and then measured in vitro the unoccupied sites with ${ }^{3} \mathrm{H}$-corticosterone in the absence or presence of the pure glucocorticoid. This experiment demonstrated in micropunched discrete areas all over the brain, the presence of two populations of receptor sites that could bind ${ }^{3} \mathrm{H}$-corticosterone with a tenfold difference in affinity. The high-affinity site was termed Type 1 corticosterone preferring (the MR) to distinguish it from the lower affinity Type 2 sites (the GR) that required stress levels of corticosterone for activation and that also bound synthetic glucocorticoids (Reul \& de Kloet 1985). From that time onward, the design of our studies was dictated by the properties and localisation of the Type 1 and Type 2 corticosterone receptor populations in the brain.

\section{Post-cloning period}

Armed with the new tools to study the brain corticosterone receptors, it was quickly established that the cloned MR was identical to the pharmacologically characterised rat brain Type 1 receptors in properties and neuro-anatomical localisation (Arriza et al. 1988, van Eekelen et al. 1988, Herman et al. 1989, Ahima et al. 1991). Highest expression of MR was found in the limbic structures, notably, the hippocampus of rats, mice, hamsters, birds and primates that was previously found to retain ${ }^{3} \mathrm{H}$-corticosterone (Rhees et al. 1972, Gerlach et al. 1976, Sutanto \& de Kloet 1987, Patel etal. 2008). The naming of the receptor was ambivalent though as the soluble brain MR did bind aldosterone as well as the naturally occurring glucocorticoids and even progesterone, hence, its promiscuous nature (Funder 2016). The discovery in 1988 by John Funder and Chris Edwards shed light on this mystery: it was found that the enzyme $11 \beta$-hydroxysteroid dehydrogenase Type 2 (HSD-2) functions as gate keeper in (among others) the kidney by inactivating the bioactive natural glucocorticoids, thus rendering aldosterone selectivity of the MR (Edwards et al. 1988, Funder et al. 1988, Funder \& Myles 1996). The 11HSD-2 is not only co-localised with MR in cells engaged in the regulation of the electrolyte balance such as the kidney tubular cells but also in discrete regions of the brain (see below). In contrast, the 11HSD-1 reductase regenerates bioactive glucocorticoids and is widely expressed in neurons and glial cells of the brain (Chapman et al. 2013).

In most brain cells, therefore, MR retains corticosterone with very high affinity. Consequently, this receptor is expected to be substantially occupied by corticosterone. Even in the morning free corticosterone (not bound to corticosteroid binding globulin (CBG) circulates in the rat in a 10- to 100-fold excess of corticosterone over aldosterone. Indeed measurement of immunoreactive steroid in purified cell nuclei of the hippocampus provided a rise of from 200 to $900 \mathrm{pg}$ corticosterone/mg DNA over the circadian cycle against a surprisingly steady 20 pg aldosterone/mg DNA (Yongue \& Roy 1987). Thus, the amount of aldosterone in the hippocampal cell nuclei is only $10 \%$ of corticosterone and started decreasing towards the circadian peak. At the start of the inactive period, corticosterone is mainly retained by MR in the nucleus, whereas at the start of the active period, the hormone is additionally bound to GR.

What is the significance of a brain MR that, even under basal conditions, is largely occupied by the natural ligand? An immediate response to that question is that the receptor rather than the ligand is the rate-limiting step, as John Funder once remarked when he visited the Rudolf Magnus Institute in Utrecht on one of his global excursions. This implies that one would like to know the turnover of the receptor rather than the level of expression as indication of receptor activity for instance by measuring its proteasome-dependent clearance (Conway-Campbell et al. 2007).

\section{Neuroendocrinology, volume regulation and spatial learning}

If the MR is always substantially occupied with ligand, we reasoned that this receptor should have something to do with the regulation of the set point of the HPA axis under basal conditions (de Kloet \& Reul 1987). Using adrenalectomised animals that were replaced with corticosterone, more or less mimicking amounts required for differential occupancy of MR and GR Mary Dallman's group indeed demonstrated that saturation of the MR was important for basal HPA axis activity (Dallman et al. 1989). Intracerebroventricular (i.c.v.) and intrahippocampal administration of the novel MR antagonist RU28318 increased basal am and pm HPA axis activity and potentiated the initial release of ACTH and corticosterone during stress exposure (Ratka et al. 1989, van Haarst et al. 1997). In humans, higher systemic

Published by Bioscientifica Ltd. 
doses of the MR antagonist spironolactone also increased basal and stress-induced cortisol secretion (Cornelisse et al. 2011).

The brain MR also appeared to affect autonomic outflow and the blood pressure response to a stressor. We found that i.c.v. administration of the MR antagonist RU28318 caused a slow and long-lasting suppression of the stress-induced pressor response (van den Berg et al. 1990). The stressor was actually the tail sphygmometry procedure itself that was used as an indirect method of blood pressure measurement, which involved training of the animal to the restraint in a plexiglass container and exposure to a warm lamp to facilitate blood flow by releasing the tail sphincter. However, with direct telemetric recording, the depressor effect of the MR antagonist could only be measured if the tail-cuff conditions (warming and restraint stress) were applied (van den Berg et al. 1994, de Kloet et al. 2000). The depressor effect was more profound in the DOCA salt model and was abolished after denervation of the kidney (Rahmouni et al. 1999, 2001). Interestingly, Gomez-Sanchez had discovered previously increased blood pressure after i.c.v. administration of the agonist aldosterone (Gomez-Sanchez 1986, 2014). As will be pointed out below, these MR agonist and antagonist effects could possibly be explained by the manipulation of MR in the nucleus tractus solitarii (NTS), which would explain the long delay in effect after injection of the antagonist in the lateral ventricles.

At the behavioural level MR function was tested by either administering an MR antagonist i.c.v. or after replacement of adrenalectomised animals with doses of corticosterone that were just sufficient to occupy the MR but too low to activate GR. These experiments performed e.g. in the Morris maze revealed yet another aspect of MR function. Melly Oitzl discovered that the i.c.v.administered MR antagonist was only effective when given briefly (15 min) prior to the memory retrieval task. In this task, the rats quickly learn to localise a hidden platform in a pool of opaque water using the spatial context, which is typical for the role of hippocampus in spatial learning. When the animal is tested for memory performance at $24 \mathrm{~h}$ after learning and the hidden platform is removed (the so-called probe trial), adrenally intact control rats will continue swimming in the area where the platform was previously located. An adrenally intact animal treated with the MR antagonist i.c.v. $15 \mathrm{~min}$ before the memory retrieval will initially visit the original platform location, but subsequently start to look for an alternative escape route. This observation led us to propose that the hippocampal MRs are involved in the selection of a behavioural strategy in search of an escape route (Oitzl \& de Kloet 1992).

Subsequent studies showed that activation of MR not only rapidly promotes memory retrieval but also mediates with short delay the effect of corticosterone on selective attention, reactivity to novel situations and encoding of the experience for memory storage. The memory traces are encoded for appropriate retrieval at a later time in the same context. These rapid effects mediated by MR occur in rodents (Oitzl \& de Kloet 1992, Oitzl et al. 1994, Khaksari et al. 2007), birds (Sandi \& Rose 1994) and in response to cortisol in humans (Cornelisse et al. 2011). The effects of corticosterone mediated by the GR are complementary to MR. Thus, blockade of GR after learning prevented memory consolidation of the encoded experience and behavioural response (Oitzl et al. 1992). The GR-mediated effects are gene dependent and observed after systemic, i.c.v. and intra-hippocampal administration of the anti-glucocorticoids. The memory consolidation effect involves GR homodimers as it was abolished in mutants carrying a point mutation, which prevents dimerisation (Oitzl et al. 2001).

In neuroendocrine regulation, GR operates complementary to MR. Under basal am conditions, the occupancy of GR is too low and therefore the antiglucocorticoid mifepristone is ineffective. However, the initial HPA axis response after stress is rapidly attenuated by the GR antagonist rather than enhanced as is observed after the MR antagonist. Subsequently, circulating stress-induced corticosteroid levels remained high for a prolonged period because mifepristone interferes with glucocorticoid feedback (Ratka et al. 1989, van Haarst et al. 1997). Also, in volume regulation, the actions mediated via GR are complementary to those mediated by MR. For instance, a single i.c.v. mifepristone administration caused a longer-lasting and more prolonged increase in the systolic pressor response rather than the decrease after central MR blockade, when measured with the tail-cuff method (van den Berg et al. 1990).

Thus, glucocorticoids act as a double-edged sword in coordination of brain and behaviour. MR controls basal and stress-induced activity of the HPA axis, sympathetic outflow and selection of a behavioural (coping) strategy. GR subsequently suppresses stress-induced activations while promoting memory storage of the experience for future use. http://joe.endocrinology-journals.org DOI: $10.1530 / \mathrm{JOE}-16-0660$
(C) 2017 Society for Endocrinology Printed in Great Britain
Published by Bioscientifica Ltd 


\section{MR and neuronal excitability}

Although it was realised in the nineties that corticosterone binds to brain MR and thus influences neuroendocrine regulation and behaviour, the steps between binding and function were unclear. This was gradually revealed by electrophysiological experiments.

In a large series of experiments, it was found that corticosterone affects many properties of hippocampal CA1 pyramidal neurons, after a U-shaped dosedependent curve (Joëls \& de Kloet 1992, 1994, Joëls 2006, Joëls et al. 2012). As an example of corticosteroid actions on CA1, neurons can serve the hormone's effect on serotonin (5-HT) transmission. Activation of 5-HT1A receptors in hippocampal CA1 cells is known to increase the conductance of an inwardly rectifying K-channel, causing the membrane to hyperpolarise. We reported that in the absence of corticosterone (i.e., in adrenalectomised rats), activation of 5-HT1A receptors leads to a large hyperpolarisation compared to the condition that low levels of corticosterone are present. Selective activation of MRs was indeed found to be associated with very small responses to 5-HT. If GRs were additionally activated (e.g., as occurs after stress), a slow enhancement in 5-HT1A receptormediated hyperpolarisation response was observed (Joëls et al. 1991). The latter depended on DNA binding of GR homodimers (Hesen et al. 1996, Karst et al. 2000). Very similar principles were found to hold for the influx of calcium through L-type voltage-dependent calcium channels, as well as properties that are linked to this calcium influx such as the attenuation of firing frequency upon a steady depolarisation of cells (Joëls \& de Kloet 1990, Chameau et al. 2007).

Dentate granule cells were also reported to be exquisitely sensitive to corticosterone acting via MR. Thus, in the absence of MR activation, the cell cycle of dentate cells accelerates, leading to both increased neurogenesis and apoptotic cell death (Wong \& Herbert 2005). In addition, MR activation is a prerequisite to maintain the complexity of granule cell dendritic trees. Interestingly, in these cells, GR function is somehow not always translated from the transcriptional to the protein level, yielding a sigmoidal rather than a U-shaped dose dependency (Joëls 2006, 2007, van Gemert et al. 2009).

MR activation of hippocampal cells seems to be a necessary condition for viability of neurons and steady transfer of excitatory signals. GR-dependent actions develop against this background of MR signalling to restore transiently raised excitability. Printed in Great Britain

\section{Synthesis}

In the years after the post-cloning hype, brain MR research has produced new data to such an extent that synthesis is possible. Here, we will discuss the identification of a neuronal network responsive after aldosterone in brain, the discovery of non-genomic MR-mediated actions on neuronal excitability, the use of genetically modified and other MR-based animal models and the remarkable role of MR gene variations in resilience and health.

\section{The aldosterone-responsive MR neuronal network}

Epithelial cells in e.g. kidney, bladder, colon and sweat glands are targets for aldosterone in the regulation of salt retention. In these tissues, aldosterone activates the MR and its downstream target genes, i.e. serum and glucocorticoid-induced kinase (SGK-1), the ubiquitin ligase NEDD4-2 and the epithelial sodium channel (EnAC) to promote $\mathrm{Na}$ resorption. This mechanism also seems to underly sensory salt detection in the tongue, whereas it is thought to regulate a circumventricular organ-based circuit involved in detection of changes in osmotic balance by a hypothesised $\mathrm{Na}^{+}$sensor (Fu \& Vallon 2014). Some authors have postulated a role in salt appetite and volume regulation of local synthesis of aldosterone in the hypothalamus and circumventricular organs (Wang et al. 2016), but see a commentary by Funder (2005). The action exerted by aldosterone on salt appetite may occur in synergy with angiotensin II, as was observed in the salt-depleted animal model generated by furosemide administration (Sakai et al. 1986, Krause \& Sakai 2007).

Recently, aldosterone-induced salt appetite was found to be under control of a small group of neurons in the caudal part of the NTS. The seminal finding to arrive at this conclusion was by Roland and coworkers (Roland et al. 1995) who observed that 11HSD-2 was expressed in a similar NTS area as previously observed for MR mRNA (Arriza et al. 1988). Then Geerling and coworkers (Geerling et al. 2006) demonstrated strong signals of colocalisation of 11HSD-2 and MR using immunocytochemistry in the caudal NTS. A weak colocalisation signal was also observed in some other circumventricular organs (subfornical and subcommissural organs) and in the ventromedial nucleus of the hypothalamus. The MR-NTS neurons connect to the nearby area postrema, a periventricular region that is readily accessible to peptides and other compounds in the 4th ventricle. i.c.v. infusion of the MR agonist aldosterone into the 4 th, but not the lateral ventricles, increased salt

Published by Bioscientifica Ltd. 
appetite (Formenti et al. 2013); and MR knockdown in the NTS prevented this aldosterone-induced salt appetite (Koneru et al. 2014).

Mutant mice with a conditional knockout of the 11HSD-2 gene selectively in the NTS showed increased salt appetite, but only when offered saline. The salt uptake of these mutants was three-fold higher than that of the controls (Evans et al. 2016). Systemic spironolactone could not entirely block the increased salt appetite. This is in support with previous pioneering work of Alan Epstein and Randall Sakai showing that in salt-depleted animal, the increased salt appetite is fully blocked when in addition to spironolactone also an angiotensin antagonist is administered (Sakai et al. 1986). Salt appetite was not a consequence of a decreased detection threshold.

The 11HSD-2-mutant mice offered saline also showed increased systolic and diastolic blood pressure, particularly in the dark phase of the circadian cycle. The reasoning is that in the absence of 11HSD-2, the MR will be occupied by corticosterone, which circulates in much higher concentrations than aldosterone. Indeed, the rise in blood pressure is attenuated after suppression of corticosterone secretion by dexamethasone even though the synthetic steroid or excess corticosterone also exert a pressor effect by itself (van den Berg et al. 1990, Gomez Sanchez 2014). Mutants receiving a salt diet became hypertensive, whereas controls receiving the same diet remained normotensive and were thus salt resistant. Blood pressure normalised again when salt was removed. Renal sodium excretion was not affected in the mutants suggesting that volume expansion was not underlying the pressor effect. Rather, the pressor response to phenylephrine was enhanced, and the baroreflex was impaired in the mutants. Although blood pressure was not measured after spironolactone in this study, the salt-sensitive rise in blood pressure seems to involve an enhanced MR-dependent sympathetic drive (Evans et al. 2016). The data are thus consistent with the previous finding that spironolactone i.c.v. decreased the pressor response by attenuating sympathetic outflow (Rahmouni et al. 1999).

Aldosterone targets the MR-NTS neuronal network in the regulation of salt appetite and reciprocally sympathetic outflow, cardiovascular functions and behaviour.

MR-NTS neurons are innervated by afferent projections from the vagus nerve carrying microbiomal information from the gut and the gastro-intestinal tract. There are also afferents from sensory neurons to the NTS that detect sodium in the taste buds of the tongue for further processing in the chorda tympani branch of cranial nerve VII.
Efferents of the MR-NTS neurons project to the parabrachial nucleus, central amygdala, paraventricular nucleus and hippocampus. There are also projections to the bed nucleus of the striae terminalis (BNST), which is a hub in the network from where efferents run to orexin neurons implicated in arousal. BNST neurons innervate the limbic brain and the nucleus accumbens underlying motivation and reward behaviours likely with the goal to still salt appetite. Pathways from the nucleus accumbens and paraventricular neurons subsequently signal salt satiation and then aversion (Geerling et al. 2006, Krause \& Sakai 2007, Geerling \& Loewy 2008, 2009). This neuronal network may explain why interventions in the frontal brain regions such as e.g. the amygdala, can also affect aldosterone regulation of salt appetite (Sakai et al. 2000).

Salt appetite is affected by mineralocorticoids in a U-shaped dose-response manner. After adrenalectomy, salt appetite rises, which is readily normalised by aldosterone replacement, but with higher doses of the mineralocorticoid, salt appetite increases again. Glucocorticoids increase salt appetite by inducing MR and by sustaining-through activation of the mesolimbic dopaminergic level, the motivation to ingest salt (Krause \& Sakai 2007).

There is another aspect that also needs attention. This condition of high mineralocorticoid level and high salt uptake generates a phenotype with increased risk of inflammation. For instance, the deoxycorticosterone-2\% salt treated rat is a classical model for hypertension, ischaemia and enhanced pro-inflammatory cytokine action (Rocha \& Stier 2001, Young et al. 2010, Jaisser \& Farman 2016). Glucocorticoids have a potent antiinflammatory action. This led Hans Selye to postulate the 'pendulum hypothesis': actions of mineralocorticoid and glucocorticoid hormones are opposite in the maintenance of homeostasis as exemplified by their pro- and antiinflammatory actions, respectively (Selye 1952). In retrospect, this pendulum hypothesis refers to MR and GR, which mediate opposing actions on inflammation by the naturally occurring glucocorticoids.

\section{Non-genomic MR-mediated actions}

In 2005, we observed that application of corticosterone to CA1 hippocampal cells quickly and transiently increases the frequency of miniature excitatory postsynaptic currents (mEPSC), each of which represents the postsynaptic response to the spontaneous release of one glutamatecontaining vesicle. This increase is most likely caused by an enhanced release probability of the vesicles. The rapid

Published by Bioscientifica Ltd. 

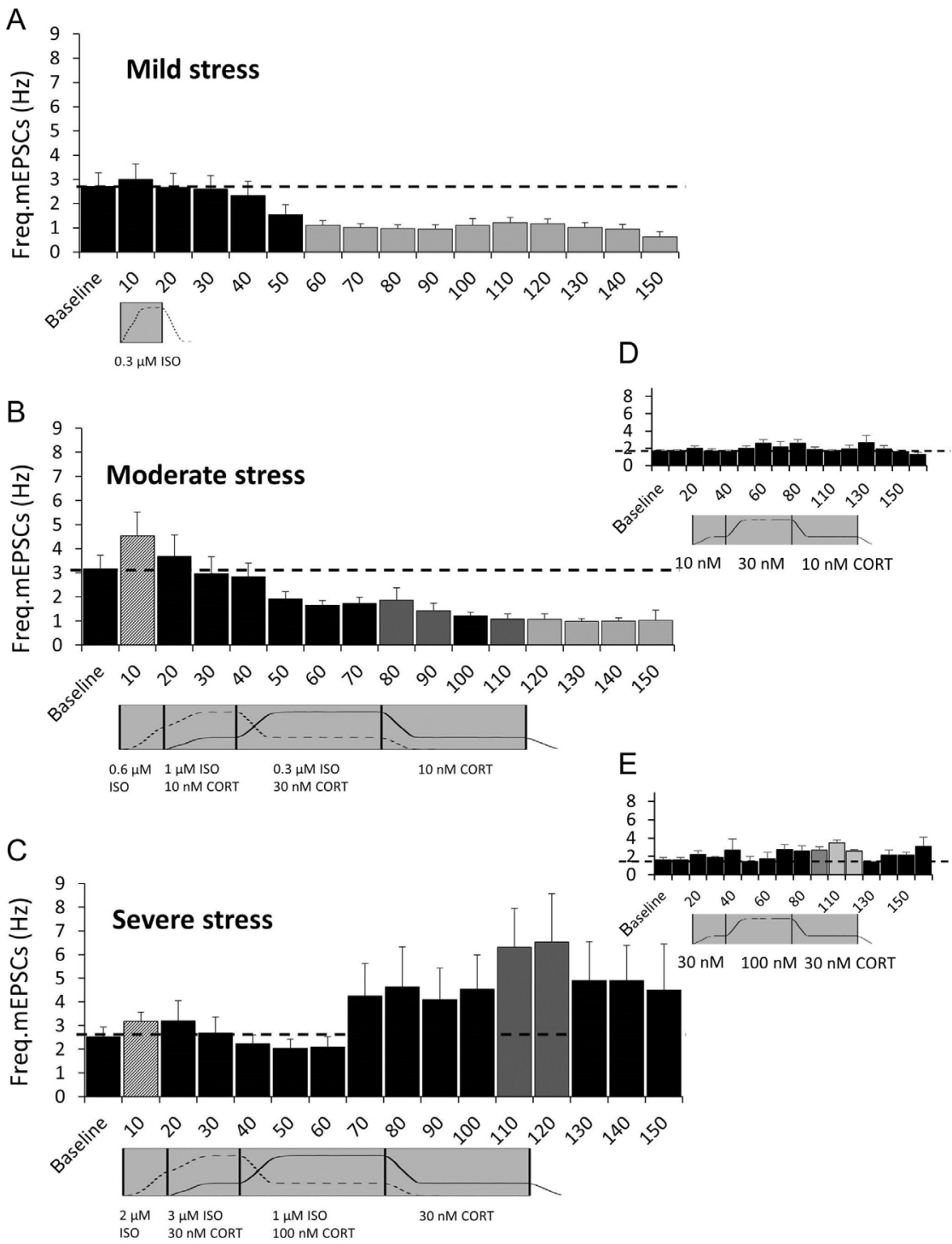

Figure 1

Basolateral cell excitability is differentially affected by waves of stress hormones, depending on the concentrations. (A) Averaged responses over time during and $>2 \mathrm{~h}$ after a wave of the $\beta$-agonist isoproterenol (ISO), administered at a low concentration. Bars represent the frequency of miniature excitatory postsynaptic currents (mEPSCs; mean +s.E.M., in Hz), based on $n=5-12$ cells per bar. In this panel as well as panels B, C, D and $\mathrm{E}$, the application scheme is shown at the bottom. The ISO and/or corticosterone (CORT) concentration indicated was perfused during the block-period marked by the vertical black lines in the schemes. The stippled line indicates the actual ISO and/or CORT concentration estimated from samples extracted in control experiments with a dye in the same set-up. (B) Averaged responses over time during and after the waves of stress hormones mimicking moderate stress. Based on $n=55-11$ cells per bar. (C) Averaged responses over time during and after waves of stress hormones mimicking severe stress conditions. Based on $n=88-15$ cells per bar. (D) Averaged responses over time during and after waves of CORT similar as used in B. Based on $n=55-10$ cells per bar. (E) Averaged responses over time during and after waves of CORT similar as used in C. Based on $n=44-11$ cells per bar. In all cases (panels A, B, C, D and $E$ ), the shading of the bars corresponds to the level of significance of the change in MEPSC frequency compared to baseline. Bars during the first block were compared to baseline with a paired Student's $t$ test; values of later bars were compared with an unpaired Student's $t$-test (in all cases uncorrected for multiple testing). Black bars: $P>0.1$ compared to baseline; striped bars: $P<0.05$ based on paired testing with baseline; dark gray bars: $P<0.05$ based on unpaired testing with baseline; light gray bars: $P<0.01$ based on unpaired testing with baseline. The data indicate that moderate-to-high concentrations rapidly increase excitability, via $\beta$-adrenergic and MR-mediated effects. In the longer term, changes in excitability strongly depend on the hormone concentrations: with low-to-moderate concentrations excitability is suppressed, whereas high concentrations result in prolonged over-excitation. The latter reflects combined late effects through $\beta$-adrenoceptors and (most likely) GRs. Data from Karst \& Joëls (2016). effect does not require protein synthesis and involves a receptor that is localised close to the plasma membrane because BSA-linked corticosterone was active outside but not inside the cell. In hippocampal CA1 neurons, this receptor seems to be located both presynaptically, linked to the ERK1/2 signalling pathway, and post-synaptically, involving G-protein signalling (Karst et al. 2005, Olijslagers et al. 2008, Sarabdjitsingh et al. 2014).

The rapid effects were abolished after pretreatment with MR antagonists and were absent in mutant mice with the forebrain MR deleted (Karst et al. 2005, Joëls et al. 2012). Relevant to this chapter, the membrane-mediated effects were obtained with concentrations of $10 \mathrm{nM}$ corticosterone or aldosterone and higher. Apparently, the pool of readily available membrane-associated MRs has a lower affinity to corticosterone than the nuclear MR. As a consequence, unlike the nuclear MR, the membrane MR can quickly respond to a rise in corticosterone level such as occurs during stress. This would lend a new and important role to the membrane MR in mediating

Published by Bioscientifica Ltd. 
stress levels of corticosterone beyond that of nuclear MRs, which are already substantially occupied under rest (Joëls et al. 2008, Groeneweg et al. 2011). Activation of the membrane MR results in the downregulation of the presynaptic Type 2 metabotropic glutamate (mGlu2) receptor presumably in response to increased glutamate release, although also a direct regulatory effect has been suggested (Nasca et al. 2015).

Principal cells in the basolateral amygdala are also capable of developing these fast MR-dependent responses in glutamate transmission. The onset of the response was slightly more gradual than that in the hippocampus and, importantly, the frequency did not return to baseline upon washout of the hormone but stayed high. This prolonged effect is gene mediated and involves the GR. The longterm change in excitability reflects the fact that rapidonset MR-mediated in cooperation with slow GR-mediated actions lastingly change the state of amygdala cells. The main consequence thereof is that these cells respond differently to a second 'hit' by corticosterone, i.e., by no response or even a decrease (as opposed to the increase) in mEPSC frequency. The latter rapid effect of the second hit depends on non-genomic actions via a GR and involves the endocannabinoid receptor 1 (Di et al. 2003). We dubbed this change in response to 'the corticosterone metaplasticity' (Karst et al. 2010).

Metaplasticity may play a role during the day because amygdala cells are hit by multiple corticosterone pulses in succession as part of the physiological ultradian release pattern of the hormone. However, also during the stress response, metaplasticity might be relevant. Recently, we reported that the $\beta$-adrenoceptor agonist isoproterenol causes enhanced mEPSC frequency in amygdala cells, similar to corticosterone. A wave of isoproterenol, through metaplasticity, also affected the response to subsequently administered corticosterone. With low-to-intermediate concentrations of isoproterenol and corticosterone (mimicking mild-to-moderate stress conditions) corticosteroid actions were subdued, so that the effects of isoproterenol prevailed. With high concentrations of both compounds, though, corticosterone actions were dominant, causing a long-lasting enhancement of excitability in the amygdala (Karst \& Joëls 2016). This may explain why events associated with such high concentrations are usually extremely well retained in memory, particularly with regard to emotional aspects that are processed via the basolateral amygdala (Fig. 1).

The response of brain cells to glucocorticoids is not necessarily always the same. The recent history of the organism may greatly affect the final outcome, as demonstrated in the basolateral amygdala. To what extent this principle also holds for other brain areas requires more investigation.

\section{MR function in limbic-forebrain regions during behaviour}

Pharmacology Rats, when exposed to an unexpected stressor, commonly respond to a single stimulus (stimulusresponse behaviour) rather than integrating multiple distal spatial cues in collecting a reward. This observation was made using a circular hole board where the presence of a reward was marked by a bottle (stimulus) as well as distal cues. By simply placing the bottle at the other side of the circular hole board, animals using the single stimulus or habit response will change to the new location of the bottle, whereas animals using a more complex spatial strategy will go to the previous (original) location. Non-stressed animals mostly use the flexible spatial hippocampal strategy, but if stressed, they engage in a cognitively less demanding intuitive habits linked to the striatum (Dias-Ferreira et al. 2009, Schwabe et al. 2010, Sousa 2016). Of note, sex differences were observed: Although males outperform females in spatial learning under basal conditions, the reverse is the case after stress (Ter Horst et al. 2013).

The stress-induced switch towards striatal-based habit learning can be blocked by i.c.v. application of the MR antagonist spironolactone. If the MR is blocked, the animals maintain the original spatial strategy (Schwabe et al. 2010, 2012, Arp et al. 2014). Similar behavioural observations were made in humans, in various tasks. Concomitant fMRI measurement revealed that tasks involving a tradeoff between simple effective strategies and complex, flexible strategies indeed show an MR-dependent switch from hippocampal towards striatal circuits under stress (Schwabe et al. 2013, Vogel et al. 2015a,b, 2016a,b).

Limbic MR activation promotes during stress the switch from deliberate hippocampal cognitive behaviour to a striatalbased habit response.

Genetic modification Stress-induced HPA axis activity is attenuated in mice with conditional overexpression of MR in the forebrain, particularly when crossed with heterozygous (GR-/-) mutants. These mutants with an increased MR:GR ratio in the forebrain (MR up and GR down) are less prone to anxiety, whereas they show better cognitive performance and perseveration of acquired behaviour (Harris et al. 2013). This phenotype previously was observed in mutant mice with forebrain-specific MR overexpression (Rozeboom et al. 2007). MR-overexpressing

Published by Bioscientifica Ltd. 
mice exposed daily for three weeks to unpredictable stressors were protected to deficits in low arousing learning tasks and showed reduction in hippocampal neurogenesis (Kanatsou et al. 2015). Similarly, rats with viral overexpression of MR in the rat dentate gyrus are resistant to impairment in an object recognition test (Ferguson \& Sapolsky 2007, 2008).

Selected lines Studies with genetically selected mouse or rat lines generally support the role of MR shown by pharmacology and genetic modification in neuroendocrinology and behaviour. Not only Lewis rats, but also spontaneous hypertensive Wistar Kyoto and apomorphine-susceptible rats, have elevated hippocampal MR expression and reduced circulating corticosterone levels (Sutanto et al. 1992, Oitzl et al. 1995). Rats selected in an elevated plus maze and open field behaviour for low anxiety (LA) show better performance in spatial memory performance, lower circulating corticosterone levels and a higher hippocampal MR expression than high anxiety (HA) animals (Herrero et al. 2006). Locomotor activity in a novel environment also has been a selection criterion. The high-reactive rodents are highly susceptible to a chronic unpredictable stressor at midlife and show cognitive deterioration during the ageing process, whereas the low-reactive rats are protected to midlife stress and show elevated hippocampal MR expression (Oitzl et al. 2000, Sandi \& Touyarot 2006).

Another example is the selection of wild mice for short-attack and long-attack latency (SAL vs LAL). The SAL mice are dominant and show a non-flexible control in the home cage with high hippocampal MR expression as opposed to the less-aggressive mice that show a flexible behavioural response and higher corticosterone levels, when faced with a novel challenge (Veenema et al. 2003). Collectively, these studies suggest that high hippocampal MR expression is associated with low anxiety, an active coping style, superior cognitive performance and low corticosterone levels, provided such animals are in control and in their own territory.

Acute stress increases hippocampal MR expression (Gesing et al. 2001, Bigio et al. 2016), but also a decrease has been reported for MR hnRNA, whereas the effects appeared to depend on strain and methodology (Herman etal. 1999). Exposure to synthetic glucocorticoids also increases hippocampal MR (Reul et al. 1987, 1989) as do tricyclic antidepressants (Seckl \& Fink 1992), whereas aged, chronically stressed and/or depressed individuals have a suppressed brain MR expression (van Eekelen et al. 1995, Klok et al. 2011b). Adult rodents that have experienced extensive maternal care as pups have higher expression of hippocampal MR than their littermates that have received poor care (Champagne et al. 2008). Handling increases, whereas adverse experiences during perinatal life cause MR downregulation in later life (de Kloet et al. 2005b).

High limbic MR is characteristic for a dominant individual that shows resilience if in control, but increased vulnerability to psychopathology during loss of control.

Genetic variation in humans Common genetic variants of the MR have been functionally characterised. The rs5522 (A/G) SNP is located in exon 2 and encodes the amino acid change isoleucine 180 to valine; the G-allele has in vitro a lower transactivation capacity for cortisol. In humans, it predicts enhanced HPA axis and autonomic reactivity, increased susceptibility for depression, impaired reward learning and increased amygdala reactivity during chronic stress (DeRijk et al. 2006, Bogdan et al. 2010, 2012). The other functional SNP is the rs2070951 (C/G), located at two nucleotides from the translation initiation site. The G-allele results in higher activity of the reninangiotensin-aldosterone system and a higher blood pressure, which would be related to the lower MR activity measured for this variant (van Leeuwen et al. 2010).

Common and functional MR haplotypes might relate to the extent of MR activation conferring inter-individual variability in susceptibility for psychopathology.

The rs5522 and rs2070951 SNPs have been studied with a haplotype approach: haplotype 1 (hap 1, GA, frequency $49 \%$ ), haplotype 2 (hap 2, CA, frequency $41 \%$ ), haplotype 3 (hap 3, CG, frequency 9\%) and haplotype 4 (hap 4, GG, which is rarely observed). Hap 2 showed the highest expression and transactivation potency in COS-1 and neuroblastoma cells (DeRijk et al. 2011, van Leeuwen et al. 2011). School teachers homozygous for hap 2 showed highest resilience on the Trier Inventory for Chronic Stress subscales 'excessive demands at work' and 'social overload' and displayed a brisk HPA axis and heart rate response in the Trier Social Stress test (van Leeuwen et al. 2011).

In females, the hap 2 carriers showed more dispositional optimism, less rumination, fewer thoughts of hopelessness and lower risk of depression (Klok et al. 2011a). In line with this is the higher implicit happiness score of MR-haplotype 2 homozygotes. Hap 2 carriers
Published by Bioscientifica Ltd 
appeared less sensitive to variations in female hormone exposure during the reproductive cycle and to the depressinogenic side effects of oral contraceptives. The MR genotype moderates the influence of oestrogen and progesterone on emotional information processing (Hamstra et al. 2015, 2016, 2017). The MR gene variants were found to sex-dependently moderate the effect of early life trauma on vulnerability to depression in a population-based cohort $(n=665)$ and an independent clinical cohort from the Netherlands Study of Depression and Anxiety $(n=1639)$. The findings of these studies suggest that MR haplotypes associate with personality traits, stress reactivity and risk for depression in a sexdependent manner in the face of early life trauma (Vinkers et al. 2015).

\section{The MR:GR balance concept}

\section{Molecular studies}

Ron Evans and Jeff Arriza (Arriza et al. 1988) predicted that 'composite gene networks of MRs and GRs may be partly overlapping and partly distinct.' They envisioned a 'binary glucocorticoid response system, which would provide a continuum of control and thus expands the range of physiological response by synergistic or competitive interactions', provided both receptors are expressed in the same cells. In hippocampus, MR and GR are co-expressed in abundance as shown by confocal microscopy (Van Steensel et al. 1996, Han et al. 2005).
The predicted composite gene networks were identified using expression profiling of the hippocampus of ADX animals replaced with a low dose of corticosterone providing predominant MR occupation. A second group of corticosterone-replaced animals receiving an additional corticosterone injection mimicking the stress response was killed $3 \mathrm{~h}$ later. The study revealed that only $20 \%$ of the genes were responsive to MR as well as GR (Datson et al. 2001, 2008). In a subsequent study, animals were first exposed to a chronic stress procedure and then received corticosterone injections. The gene patterns examined in laser-dissected hippocampal regions revealed that a history of chronic stress had profound consequences for the subsequent response to acute corticosterone challenge, differentially affecting the expression of several hundreds of genes as compared to challenged non-stressed control animals. The difference concerned an overrepresentation of genes involved in chromatin reorganisation and epigenetic processes in the stress group (Datson et al. 2013).

In another experiment using corticosterone replacement of ADX animals, chromatin immunoprecipitation followed by DNA sequencing (ChIP-seq) identified 2470 specific binding sites of which 39\% were localised within in genes (Fig. 2) (Polman et al. 2013). Of these binding sites in total 918 and 1470 were exclusive for MR and GR, respectively, whereas 475 sites were overlapping and did bind both receptors (van Weert et al. 2017). Motif analysis revealed a $100 \%$ similarity with GRE's on every binding site. In addition, an additional AtOH/NeuroD consensus sequence

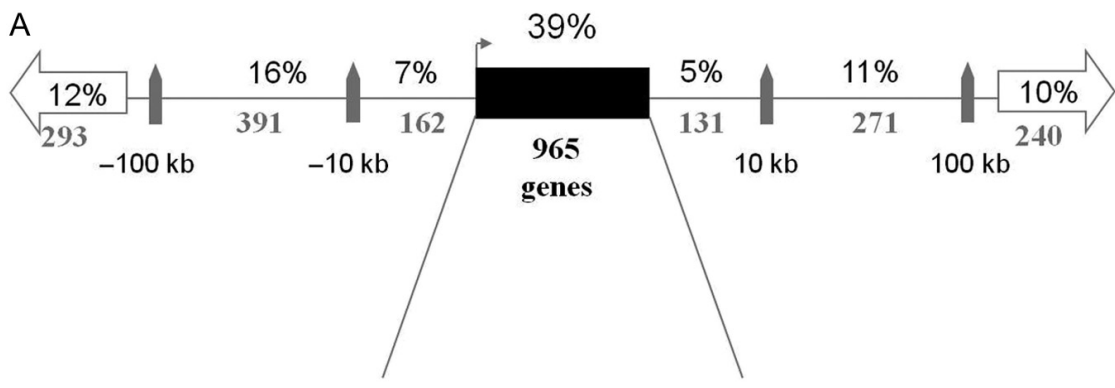

B

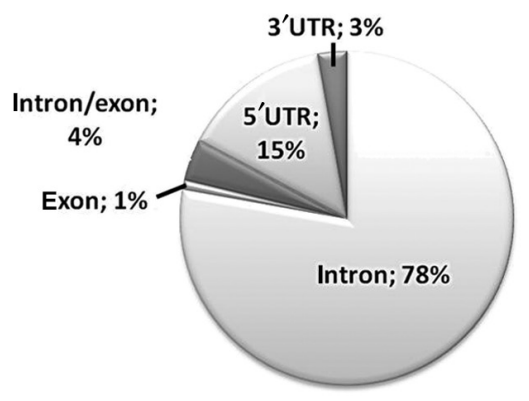

http://joe.endocrinology-journals.org DOI: 10.1530/JOE-16-0660
๑) 2017 Society for Endocrinology Printed in Great Britain
Figure 2

Genomic distribution of glucocorticoid receptorbinding sites in rat hippocampus genome. (A) Distribution of GBS relative to the nearest gene, resulting in regions that lie within or outside genes. The black bar represents a gene, showing that $39 \%$ of the GBS are located within genes. The GBS that are located upstream or downstream from the nearest gene are divided into 3 bins: within $10 \mathrm{~kb}$, between 10 and $100 \mathrm{~kb}$ and more than $100 \mathrm{~kb}$ from a gene. (B) Pie chart showing the location of intragenic GBS within annotated RefSeq genes, divided into 5'-UTR (exon or intron), intron, exon, intron/exon overlap, and 3'-UTR (exon or intron) regions. Reproduced, with permission, from Polman JA, de Kloet ER \& Datson NA, Endocrinology, volume 154, pages 1832-1844, 2013, Two populations of glucocorticoid receptor-binding sites in the male rat hippocampal genome. Copyright 2013, The Endocrine Society. See also van Weert et al. (2017) 
was found at $400 \mathrm{bp}$ from the GRE for all MR-specific binding sites only, and which was thus absent at the MRGR overlapping and GR-binding sites. In vivo, one of the members of this family of proteins, NeuroD2, was found at
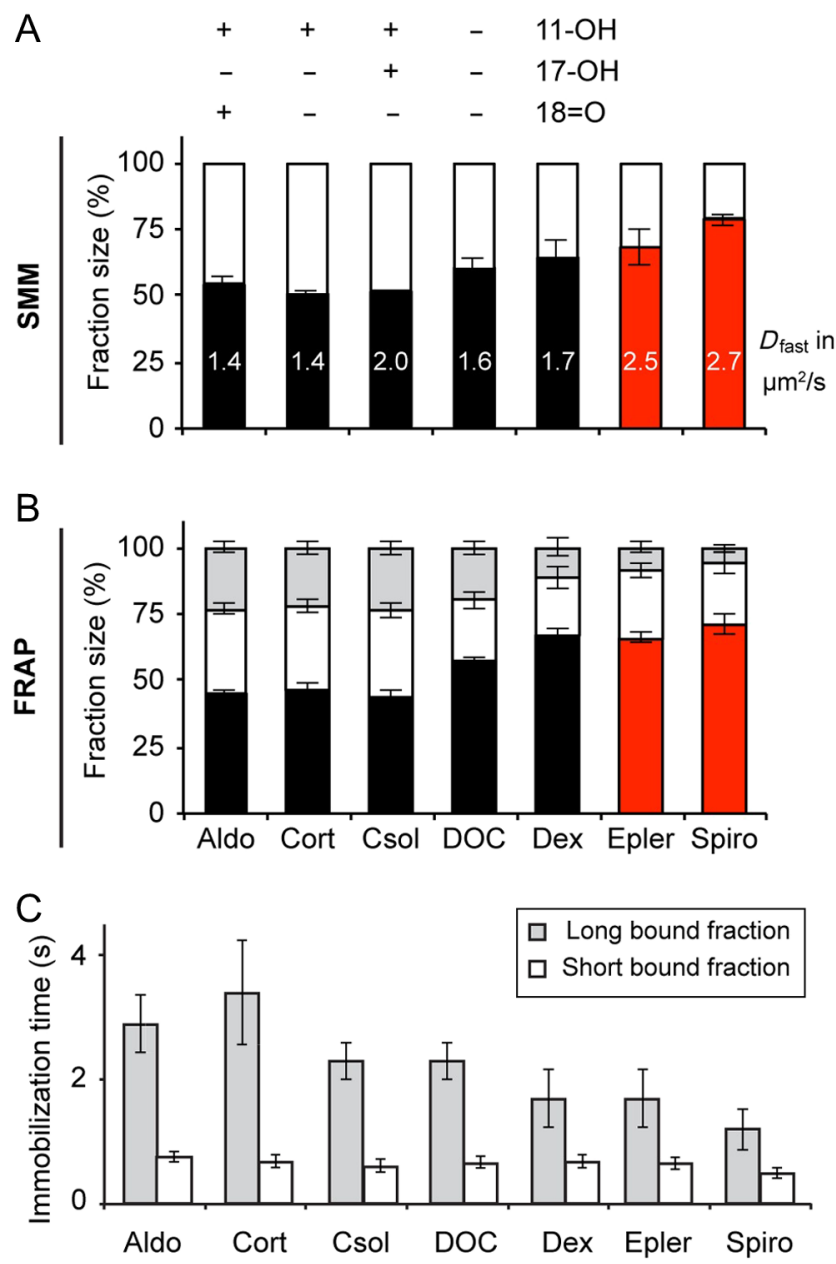

\section{Figure 3}

Ligand structure determines the nuclear mobility of the MR. A range of natural and synthetic agonists (black bars) and antagonists (red bars) were tested for their effect on the intranuclear mobility of the MR by both SMM (A) and FRAP (B and C) analysis. The MR and GR share several agonists, but the binding and functional characteristics differ. Indeed, a weak agonist for the GR, corticosterone (cort), which gave a very mobile GR, instead leads to a low mobility for the MR. A large bound fraction (SMM; white bars and FRAP; white and light grey bars combined) a low diffusion coefficient (in $\mu \mathrm{m}^{2} / \mathrm{s}$, written within its corresponding bar in A) and long immobilization times (C). Of all functional steroid side groups, only the 18-keto $(18=0)$ group appears to affect the mobility of the MR. SMM: $n=20$, FRAP: $n=30$. Data represented as total fit \pm S.E.M. (of 3 separate PICS analyses) for SMM and as average of top $10 \%$ fits \pm S.E.M. for FRAP. Aldo, aldosterone; csol, cortisol; dex, dexamethasone; DOC, deoxycorticosterone; epler, eplerenone; spiro, spironolactone. Reproduced under the terms of the original Creative Commons Attribution License, from Groeneweg FL, van Royen ME, Fenz S, Keizer VI, Geverts B, Prins J, de Kloet ER, Houtsmuller AB, Schmidt TS \& Schaaf MJ, 2014, Quantitation of glucocorticoid receptor DNA-binding dynamics by single-molecule microscopy and FRAP. PLoS ONE, volume 14, e90532.
MR-, but not at GR-exclusive binding sites (van Weert et al. 2017). The NeuroD2 proteins have a role in neuronal differentiation and studies with NeuroD2 mutants revealed their role in stress susceptibility (Bagot et al. 2016).

Two lines of evidence suggest that under stressful conditions, other layers of complexity are added to MR and GR functioning. Thus, Gray and coworkers (Gray et al. 2014) compared the effect of corticosterone exposure with that of acute stressor exposure of the chronically stressed animals and found distinctly different profiles of responsive genes such as e.g. the NFkB pathway (see also Datson et al. 2012). Furthermore, a recent sequential tandem ChIP analysis by Mifsud and Reul (2016) using tissue of stressed adrenally intact animals provided further evidence for the possible existence of overlapping MR- and GR-binding sites indicative of MR:GR heterodimers as had been previously suggested by in vitro experiments (Liu et al. 1995, Trapp \& Holsboer 1996). For the ultimate proof of heterodimers, molecular imaging approaches are necessary (for the process, see Groeneweg et al. 2014) (Fig. 3).

Previously, binding experiments were performed under basal conditions in ADX animals replaced with various doses of corticosterone and killed at $1 \mathrm{~h}$ after administration to obtain gradual activation of first MRs and then additional GRs. These experiments were originally used for discrimination of MR from GR in hippocampus cytosol, which led to the notion that nuclear MR is largely occupied already under basal conditions, whereas nuclear GR requires stress levels of corticosterone. In the ChiPseq experiments, this experimental approach led to the distinction of two populations of genomic-binding sites for MR and GR (Polman et al. 2013). One population became saturated with low corticosterone concentrations containing mostly $\mathrm{MR}$, whereas a second population required high concentrations with a much higher GR:MR ratio. However, under adrenally intact stressed conditions, high receptor occupancy did not predict the extent of DNA binding, whereas circadian variations also did not translate unequivocally to occupancy of genomicbinding sites on the three genes investigated (Mifsud \& Reul 2016). The complexity likely is caused by NeuroD, AP-1, NFkB and other transcription factors or coregulators (Zalachoras et al. 2013, van Weert et al. 2017).

Thus, NeuroD2 factor interaction seems to confer MR over GR-binding specificity to nearby GREs.

\section{Cellular and behavioural studies}

The genomic expression and binding studies reveal an enormous diversity in MR- and GR-mediated molecular

Published by Bioscientifica Ltd 
effects. At the neuronal level, these diverse actions appear translated to U-shaped or sigmoidal dose-response curves demonstrating the role of MR in maintaining high excitability and that of GR to normalise this transiently raised excitability (Joëls 2006). In hippocampal pyramidal neurons, MR and GR mediate opposing actions of corticosterone, whereas in the basal amygdala cells, concomitant $\beta$-adrenergic stimulation and a genomic GR-mediated action appears to profoundly potentiate and prolong the initial fast MR-mediated rise in excitability via enhanced glutamatergic transmission. This extended period of increased excitability will promote encoding of emotionally loaded information.

The cellular actions of the glucocorticoids mediated by MR and GR can be translated to behavioural performance. Initially, the membrane MR mediates the rapid effects on information processing underlying selective attention and memory retrieval and allocation of energy to circuits underlying the selected coping strategy (Vogel et al. 2016a). GR-mediated actions subsequently are concerned with executive functions and memory storage in preparation for future life.

How these new findings on different levels of biological complexity can be incorporated in the MR:GR balance hypothesis is a challenge. This hypothesis was inspired by Selye's pendulum hypothesis involving opposing mineralocorticoid and glucocorticoid effects on inflammation. The 'balance hypothesis' refers to the complementary MR- and GR-mediated actions of cortisol or corticosterone that coordinate physiological regulations aimed to maintain homeostasis and to promote behavioural adaptation:

'The MR:GR balance hypothesis predicts that upon imbalance of these receptor functions threats to homeostasis are less well communicated and coordinated among the various glucocorticoid targets. At a certain threshold this may lead to a condition of neuroendocrine dysregulation and impaired behavioural adaptation, which potentially can aggravate stress-related deterioration and promote susceptibility to stress-related disease for which the individual is genetically predisposed' (de Kloet \& Reul 1987, de Kloet 1991, 2014, de Kloet et al. 1998, 2005a).

The hypothesis has implications for pharmacotherapy with synthetic glucocorticoids. Dexamethasone, for instance, potently suppresses HPA axis activity leading to depletion of the MR ligands cortisol and corticosterone and thus decreased MR occupancy in the brain. As a consequence, brain functions dependent on MR may deteriorate, and this has been demonstrated in rodents (Karssen et al. 2001, 2005). Indeed, dexamethasone- treated mice showed neurological and memory deficits that could be ameliorated with corticosterone substitution (Liston \& Gan 2011, Liston et al. 2013). The finding that corticosterone acts via changes to hippocampal neuronal spines during the sleep-wake cycle received the Society for Endocrinology's 2015 award for the best article published in Journal of Endocrinology (Ikeda et al. 2015).

In humans, dexamethasone reduced slow wave sleep and caused, upon prolongation, dysphoric effects. Co-administration of cortisol restored slow wave sleep and caused an euphoric mood likely via activation of MR (Born et al. 1991, Plihal et al. 1996, Groch et al. 2013). Finally, a recent clinical trial demonstrated that dexamethasone therapy of young patients suffering from acute lymphoblastic leukaemia caused in about 30\% of these patients severe adverse neuropsychological effects and sleep disturbances, which were ameliorated by cortisol add-on in doses used for replacement of adrenally deficient patients (Warris et al. 2016). The peripheral metabolic effects are not ameliorated or aggravated by the additional low dose of cortisol. The benefit of this refill for the brain MR supports the validity of the MR:GR balance concept and demonstrates its clinical utility (Meijer \& de Kloet 2017).

\section{Perspectives}

Today, 30 years after cloning, we know that the brain harbours aldosterone-selective and corticosterone/cortisolpreferring networks that deal with processing of salty and stressful information, respectively. These steroid effects mediated by MR proceed in a complementary fashion with GR-mediated actions. The effects of corticosteroids in the brain therefore depend on a fine-tuned balance between MR and GR that upon activation shifts energy resources to circuits and alter their connectivity underlying arousal, emotional expressions of fear and aggression, cognitive performance, motivation, reward and aversion (Korte et al. 1995, Kruk et al. 2013, Hermans et al. 2014, Sousa 2016, Vogel et al. 2016a,b). Thus, aldosterone not only evokes salt appetite but also reciprocally affects limbic-forebrain functions, via MR-based NTS and circumventricular networks (Geerling \& Loewy 2008, 2009, Evans et al. 2016); the limbic-forebrain circuits themselves express abundantly MRs, which prefer corticosterone and cortisol. Aldosterone and the glucocorticoids are thus capable to affect the limbic-forebrain circuitry underlying cognitive and emotional functions (de Kloet \& Joëls 2017).

The forebrain cortisol/corticosterone preferring MR network controls autonomic, neuroendocrine and

Published by Bioscientifica Ltd. 
behavioural responses as part of a repertoire involving selective attention, memory retrieval, appraisal of salient information, selection of an appropriate coping strategy and encoding of the experience for memory storage. Thus, the MR can operate as a key regulator in a mechanism underlying resilience to stress. Such a crucial role of the brain MR in human resilience is underscored by variations in MR genotype, which were found to predict stress coping style and protection to depression, and by epigenetic modifications of the MR induced by (early) adversity (see Joëls et al. 2012, Bigio et al. 2016, de Kloet et al. 2016).

In years to come, we will learn much more about neuronal connectivity changes upon MR activation in different stressful contexts, at a time that our understanding of the human connectome is rapidly increasing. It is at present uncertain to what extent MR genetics contribute to circuit bias and how environmental stressors can modify MR function by epigenetic mechanisms. How precisely MR and GR interact on the genomic level as homodimers and heterodimers is also still poorly understood although progress is being made by the identification of the NeuroD co-activator conferring MR selectivity in hippocampus. On the cellular level, the coordinate membrane and genomic actions provide another challenge for translation to behaviour and physiological regulations (Karst \& Joëls 2016).

This essay was focused on neuronal MR and GR. The same receptors are also however expressed in brain endothelial cells and glial cells with a prominent role in e.g. vascular function, cellular defence and energy metabolism. In these cells, the MR can drive inflammatory processes in case of vascular damage and promote atherosclerosis enhancing the risk for ischaemia. To what extent this pro-inflammatory action mediated by MR underlies co-morbidity of brain, heart and metabolic disorders is an important question for new research (see Jaisser \& Farman 2016 for review).

The knowledge gained in these forthcoming studies is essential to understand the role of MR in mental health and disease multi-morbidity, to predict how pharmacological manipulation of the MR can contribute to therapeutic approaches and to appreciate that MR- and GR-mediated actions complement each other in a finetuned balance from gene to behaviour.

\section{Declaration of interest}

E R de Kloet is on the scientific advisory board of Dynacorts Therapeutics and Pharmaseed Ltd and owns stock of Corcept Therapeutics.

\section{Funding}

M J is supported by the Consortium on Individual Development (CID), which is funded through the Gravitation program of the Dutch Ministry of Education, Culture, and Science and the Netherlands Organization for Scientific Research (NWO grant number 024.001.003) and by NWO. The support to E R d K by the Royal Netherlands Academy of Arts and Sciences, COST Action ADMIRE BM1301 and STW Take-off 14095 is gratefully acknowledged

\section{References}

Ahima R, Krozowski Z \& Harlan RE 1991 Type I corticosteroid receptorlike immunoreactivity in the rat CNS: distribution and regulation by corticosteroids. Journal of Comparative Neurology 313 522-538. (doi:10.1002/cne.903130312)

Arp JM, ter Horst JP, Kanatsou S, Fernández G, Joëls M, Krugers HJ \& Oitzl MS 2014 Mineralocorticoid receptors guide spatial and stimulusresponse learning in mice. PLOS ONE 9 e86236. (doi:10.1371/journal. pone.0086236)

Arriza JL, Weinberger C, Cerelli G, Glaser TM, Handelin BL, Housman DE \& Evans RM 1987 Cloning of human mineralocorticoid receptor complementary DNA: structural and functional kinship with the glucocorticoid receptor. Science 237 268-275. (doi:10.1126/ science.3037703)

Arriza JL, Simerly RB, Swanson LW \& Evans RM 1988 The neuronal mineralocorticoid receptor as a mediator of glucocorticoid response. Neuron 1 887-900. (doi:10.1016/0896-6273(88)90136-5)

Bagot RC, Cates HM, Purushothaman I, Lorsch ZS, Walker DM, Wang J, Huang X, Schlüter OM, Maze I, Peña CJ, et al. 2016 Circuit wide transcriptional profiling reveals brain region-specific gene networks regulating depression susceptibility. Neuron 90 969-983. (doi:10.1016/j.neuron.2016.04.015)

Beaumont K \& Fanestil DD 1983 Characterization of rat brain aldosterone receptors reveals high affinity for corticosterone. Endocrinology $\mathbf{1 1 3}$ 2043-2051. (doi:10.1210/endo-113-6-2043)

Bigio B, Mathé AA, Sousa VC, Zelli D, Svenningsson P, McEwen BS \& Nasca C 2016 Epigenetics and energetics in ventral hippocampus mediate rapid antidepressant action: Implications for treatment resistance. PNAS 113 7906-7911. (doi:10.1073/pnas.1603111113)

Bogdan R, Perlis RH, Fagerness J \& Pizzagalli DA 2010 The impact of mineralocorticoid receptor ISO/VAL genotype (rs5522) and stress on reward learning. Genes, Brain and Behavior 9 658-667. (doi:10.1111/ j.1601-183X.2010.00600)

Bogdan R, Williamson DE \& Hariri AR 2012 Mineralocorticoid receptor Iso/Val (rs5522) genotype moderates the association between previous childhood emotional neglect and amygdala reactivity. American Journal of Psychiatry 169 515-522. (doi:10.1176/appi. ajp.2011.11060855)

Bohus B \& Lissák K 1968 Adrenocortical hormones and avoidance behaviour of rats. International Journal of Neuropharmacology $\mathbf{7}$ 301-306. (doi:10.1016/0028-3908(68)90012-9)

Born J, de Kloet ER, Wenz H \& Fehm HL 1991 Gluco- and mineralocorticoid effects on human sleep: a role of central corticosteroid receptors. American Journal of Physiology $\mathbf{2 6 0}$ 183-188.

Chameau P, Qin Y, Spijker S, Smit AB \& Joëls M 2007 Glucocorticoids specifically enhance L-type calcium current amplitude and affect calcium channel subunit expression in the mouse hippocampus. Journal of Neurophysiology 97 5-14. (doi:10.1152/jn.00821.2006)

Champagne DL, Bagot RC, van Hasselt F, Ramakers G, Meaney MJ, de Kloet ER, Joëls M \& Krugers H 2008 Maternal care and hippocampal plasticity: evidence for experience-dependent structural plasticity,

Published by Bioscientifica Ltd. http://joe.endocrinology-journals.org

DOI: $10.1530 / J O E-16-0660$
(C) 2017 Society for Endocrinology Printed in Great Britain 
altered synaptic functioning, and differential responsiveness to glucocorticoids and stress. Journal of Neuroscience 28 6037-6045 (doi:10.1523/JNEUROSCI.0526-08.2008)

Chapman K, Holmes M \& Seckl J 2013 11ß-Hydroxysteroid dehydrogenases: intracellular gate-keepers of tissue glucocorticoid action. Physiological Reviews 93 1139-1206. (doi:10.1152/ physrev.00020.2012)

Conway-Campbell BL, McKenna MA, Wiles CC, Atkinson HC, de Kloet ER \& Lightman SL 2007 Proteasome-dependent downregulation of activated nuclear hippocampal glucocorticoid receptors determines dynamic responses to corticosterone. Endocrinology 148 5470-5477. (doi:10.1210/en.2007-0585)

Cornelisse S, Joëls M \& Smeets T 2011 A randomized trial on mineralocorticoid receptor blockade in men: effects on stress responses, selective attention, and memory. Neuropsychopharmacology 36 2720-2728. (doi:10.1038/npp.2011.162)

Dallman MF, Levin N, Cascio CS, Akana SF, Jacobson L \& Kuhn RW 1989 Pharmacological evidence that the inhibition of diurnal adrenocorticotropin secretion by corticosteroids is mediated via type I corticosterone-preferring receptors. Endocrinology 124 2844-2850. (doi:10.1210/endo-124-6-2844)

Datson NA, van der Perk J, de Kloet ER \& Vreugdenhil E 2001 Identification of corticosteroid-responsive genes in rat hippocampus using serial analysis of gene expression. European Journal of Neuroscience 14 675-689. (doi:10.1046/j.0953816x.2001.01685.x)

Datson NA, Morsink MC, Meijer OC \& de Kloet ER 2008 Central corticosteroid actions: Search for gene targets. European Journal of Pharmacology 583 272-289. (doi:10.1016/j.ejphar.2007.11.070)

Datson NA, Speksnijder N, Mayer JL, Steenbergen PJ, Korobko O, Goeman J, de Kloet ER, Joëls M \& Lucassen PJ 2012 The transcriptional response to chronic stress and glucocorticoid receptor blockade in the hippocampal dentate gyrus. Hippocampus 22 359-371. (doi:10.1002/hipo.20905)

Datson NA, van den Oever JM, Korobko OB, Magarinos AM, de Kloet ER \& McEwen BS 2013 Previous history of chronic stress changes the transcriptional response to glucocorticoid challenge in the dentate gyrus region of the male rat hippocampus. Endocrinology 154 3261-3272. (doi:10.1210/en.2012-2233)

de Kloet ER 1991 Brain corticosteroid receptor balance and homeostatic control. Frontiers in Neuroendocrinology 12 95-164.

de Kloet ER 2014 From receptor balance to rational glucocorticoid therapy. Endocrinology 155 2754-2769. (doi:10.1210/en.2014-1048)

de Kloet ER \& Reul JM 1987 Feedback action and tonic influence of corticosteroids on brain function: a concept arising from the heterogeneity of brain receptor systems. Psychoneuroendocrinology 12 83-105. (doi:10.1016/0306-4530(87)90040-0)

de Kloet ER \& Joëls M 2017 Brain mineralocorticoid receptor function in control of salt balance and stress-adaptation. Physiology and Behavior [in press]. (doi:10.1016/j.physbeh.2016.12.045)

de Kloet ER, van der Vies J \& de Wied D 1974 The site of the suppressive action of dexamethasone on pituitary-adrenal activity. Endocrinology 94 61-73. (doi:10.1210/endo-94-1-61)

de Kloet R, Wallach G \& McEwen BS 1975 Differences in corticosterone and dexamethasone binding to rat brain and pituitary. Endocrinology 96 598-609. (doi:10.1210/endo-96-3-598)

de Kloet ER, Vreugdenhil E, Oitzl MS \& Joëls M 1998 Brain corticosteroid receptor balance in health and disease. Endocrine Reviews 19 269-301. (doi:10.1210/edrv.19.3.0331)

de Kloet ER, van Acker SA, Sibug RM, Oitzl MS, Meijer OC, Rahmouni K \& de Jong W 2000 Brain mineralocorticoid receptors and centrally regulated functions. Kidney International 57 1329-1336. (doi:10.1046/ j.1523-1755.2000.00971.x)

de Kloet ER, Joëls M \& Holsboer F 2005a Stress and the brain: from adaptation to disease. Nature Reviews Neuroscience 6 463-475. (doi:10.1038/nrn1683) de Kloet ER, Sibug RM, Helmerhorst FM \& Schmidt MV 2005 $b$ Stress, genes and the mechanism of programming the brain for later life. Neuroscience and Biobehavioral Reviews 29 271-281. (doi:10.1016/j. neubiorev.2004.10.008)

de Kloet ER, Otte C, Kumsta R, Kok L, Hillegers MH, Hasselmann H, Kliegel D \& Joëls M 2016 STRESS and DEPRESSION a crucial role of the mineralocorticoid receptor. Journal of Neuroendocrinology $\mathbf{2 8}$ article 12379. (doi:10.1111/jne.12379)

De Nicola AF, Tornello S, Weisenberg L, Fridman O \& Birmingham MK 1981 Uptake and binding of [3H]aldosterone by the anterior pituitary and brain regions in adrenalectomized rats. Hormone and Metabolic Research 13 103-106. (doi:10.1055/s-2007-1019185)

DeRijk RH, Wüst S, Meijer OC, Zennaro MC, Federenko IS, Hellhammer DH, Giacchetti G, Vreugdenhil E, Zitman FG \& de Kloet ER 2006 A common polymorphism in the mineralocorticoid receptor modulates stress responsiveness. Journal of Clinical Endocrinology and Metabolism 91 5083-5089. (doi:10.1210/jc.2006-0915)

DeRijk RH, de Kloet ER, Zitman FG \& van Leeuwen N 2011 Mineralocorticoid receptor gene variants as determinants of HPA axis regulation and behavior. Endocrine Development 20 137-148. (doi:10.1159/000321235)

Di S, Malcher-Lopes R, Halmos KC \& Tasker JG 2003 Nongenomic glucocorticoid inhibition via endocannabinoid release in the hypothalamus: a fast feedback mechanism. Journal of Neuroscience $\mathbf{2 3}$ 4850-4857.

Dias-Ferreira E, Sousa JC, Melo I, Morgado P, Mesquita AR, Cerqueira JJ, Costa RM \& Sousa N 2009 Chronic stress causes frontostriatal reorganization and affects decision-making. Science 31 621-625. (doi:10.1126/science.1171203)

Edwards CR, Stewart PM, Burt D, Brett L, Mcintyre MA, Sutanto WS, De Kloet ER \& Monder C 1988 Localisation of 11 beta-hydroxysteroid dehydrogenase - tissue specific protector of the mineralocorticoid receptor. Lancet 2 986-989. (doi:10.1016/S0140-6736(88)90742-8)

Ermisch A \& Rühle HJ 1978 Autoradiographic demonstration of aldosterone-concentrating neuron populations in rat brain. Brain Research 147 154-158. (doi:10.1016/0006-8993(78)90780-1)

Evans LC, Ivy JR, Wyrwoll C, McNairn JA, Menzies RI, Christensen TH, Al-Dujaili EA, Kenyon CJ, Mullins JJ \& Seckl JR, et al. 2016 Conditional deletion of Hsd11b2 in the brain causes salt appetite and hypertension. Circulation 133 1360-1370. (doi:10.1161/ CIRCULATIONAHA.115.019341)

Ferguson D \& Sapolsky R 2007 Mineralocorticoid receptor overexpression differentially modulates specific phases of spatial and nonspatial memory. Journal of Neuroscience 27 8046-8052. (doi:10.1523/ JNEUROSCI.1187-07.2007)

Ferguson D \& Sapolsky R 2008 Overexpression of mineralocorticoid and transdominant glucocorticoid receptor blocks the impairing effects of glucocorticoids on memory. Hippocampus 18 1103-1111. (doi:10.1002/hipo.20467)

Formenti S, Bassi M, Nakamura NB, Schoorlemmer GH, Menani JV \& Colombari E 2013 Hindbrain mineralocorticoid mechanisms on sodium appetite. American Journal of Physiology: Regulatory Integrative and Comparative Physiology 304 R252-R259. (doi:10.1152/ ajpregu.00385.2011)

Fu Y \& Vallon V 2014 Mineralocorticoid-induced sodium appetite and renal salt retention: evidence for common signaling and effector mechanisms. Nephron Physiology 128 8-16. (doi:10.1159/000368264)

Funder JW 2005 How do central mineralocorticoid receptors modulate blood pressure? American Journal of Physiology: Regulatory Integrative and Comparative Physiology 288 R356-R357. (doi:10.1152/ ajpregu.00753.2004)

Funder JW 2016 The promiscuous mineralocorticoid receptor. Hypertension 67 839-840. (doi:10.1161/HYPERTENSIONAHA. 116.07180)

Funder JW \& Myles K 1996 Exclusion of corticosterone from epithelial mineralocorticoid receptors is insufficient for selectivity of 
aldosterone action: in vivo binding studies. Endocrinology 137 5264-5268. (doi:10.1210/en.137.12.5264)

Funder JW, Pearce PT, Smith R \& Smith AI 1988 Mineralocorticoid action: target tissue specificity is enzyme, not receptor, mediated. Science $\mathbf{2 4 2}$ 583-585. (doi:10.1126/science.2845584)

Fuxe K, Wikström AC, Okret S, Agnati LF, Härfstrand A, Yu ZY, Granholm L, Zoli M, Vale W \& Gustafsson JA 1985 Mapping of glucocorticoid receptor immunoreactive neurons in the rat tel- and diencephalon using a monoclonal antibody against rat liver glucocorticoid receptor. Endocrinology 117 1803-1812. (doi:10.1210/endo-117-5-1803)

Geerling JC \& Loewy AD 2008 Central regulation of sodium appetite. Experimental Physiology 93 177-209. (doi:10.1113/ expphysiol.2007.039891)

Geerling JC \& Loewy AD 2009 Aldosterone in the brain. American Journal of Physiology: Renal Physiology 297 F559-F576. (doi:10.1152/ ajprenal.90399.2008)

Geerling JC, Kawata M \& Loewy AD 2006 Aldosterone-sensitive neurons in the rat central nervous system. Journal of Comparative Neurology 494 515-527. (doi:10.1002/cne.20808)

Gerlach JL \& McEwen BS 1972 Rat brain binds adrenal steroid hormone: radioautography of hippocampus with corticosterone. Science $\mathbf{1 7 5}$ 1133-1136. (doi:10.1126/science.175.4026.1133)

Gerlach JL, McEwen BS, Pfaff DW, Moskovitz S, Ferin M, Carmel PW \& Zimmerman EA 1976 Cells in regions of rhesus monkey brain and pituitary retain radioactive estradiol, corticosterone and cortisol differentially. Brain Research 103 603-612. (doi:10.1016/00068993(76)90463-7)

Gesing A, Bilang-Bleuel A, Droste SK, Linthorst AC, Holsboer F \& Reul JMHM 2001 Psychological stress increases hippocampal mineralocorticoid receptor levels: involvement of corticotropinreleasing hormone. Journal of Neuroscience 21 4822-4829.

Gomez-Sanchez EP 1986 Intracerebroventricular infusion of aldosterone induces hypertension in rats. Endocrinology 118 819-823. (doi:10.1210/endo-118-2-819)

Gomez-Sanchez EP 2014 Brain mineralocorticoid receptors in cognition and cardiovascular homeostasis. Steroids 91 20-31. (doi:10.1016/j. steroids.2014.08.014)

Gray JD, Rubin TG, Hunter RG \& McEwen BS 2014 Hippocampal gene expression changes underlying stress sensitization and recovery. Molecular Psychiatry 19 1171-1178. (doi:10.1038/mp.2013.175)

Groch S, Wilhelm I, Lange T \& Born J 2013 Differential contribution of mineralocorticoid and glucocorticoid receptors to memory formation during sleep. Psychoneuroendocrinology 38 2961-2972. (doi:10.1016/j. psyneuen.2013.08.006)

Groeneweg FL, Karst H, de Kloet ER \& Joëls M 2011 Rapid non-genomic effects of corticosteroids and their role in the central stress response. Journal of Endocrinology 209 153-167. (doi:10.1530/JOE-10-0472)

Groeneweg FL, van Royen ME, Fenz S, Keizer VI, Geverts B, Prins J, de Kloet ER, Houtsmuller AB, Schmidt TS \& Schaaf MJ 2014 Quantitation of glucocorticoid receptor DNA-binding dynamics by single-molecule microscopy and FRAP. PLoS ONE 14 e90532. (doi:10.1371/journal. pone.0090532)

Hamstra DA, de Kloet ER, van Hemert AM, de Rijk RH \& Van der Does W 2015 Mineralocorticoid receptor haplotype, oral contraceptives and emotional information processing. Neuroscience 24 1855-1859.

Hamstra DA, de Kloet ER, Tollenaar M, Verkuil B, Manai M, Putman P \& Van der Does W 2016 Mineralocorticoid receptor haplotype moderates the effects of oral contraceptives and menstrual cycle on emotional information processing. Journal of Psychopharmacology 30 1054-1061. (doi:10.1177/0269881116647504)

Hamstra DA, de Kloet ER, Quataert I, Jansen M \& Van der Does W 2017 Mineralocorticoid receptor haplotype, estradiol, progesterone and emotional information processing. Psychoneuroendocrinology 76 162-173. (doi:10.1016/j.psyneuen.2016.11.037)

Han F, Ozawa H, Matsuda K, Nishi M \& Kawata M 2005 Colocalization of mineralocorticoid receptor and glucocorticoid receptor in the hippocampus and hypothalamus. Neuroscience Research 51 371-381. (doi:10.1016/j.neures.2004.12.013)

Harris AP, Holmes MC, de Kloet ER, Chapman KE \& Seckl JR 2013 Mineralocorticoid and glucocorticoid receptor balance in control of HPA axis and behaviour. Psychoneuroendocrinology 38 648-658. (doi:10.1016/j.psyneuen.2012.08.007)

Herman JP, Patel PD, Akil H \& Watson SJ 1989 Localization and regulation of glucocorticoid and mineralocorticoid receptor messenger RNAs in the hippocampal formation of the rat. Molecular Endocrinology 3 1886-1894. (doi:10.1210/mend-3-11-1886)

Herman JP, Watson SJ \& Spencer RL 1999 Defense of adrenocorticosteroid receptor expression in rat hippocampus: effects of stress and strain. Endocrinology 140 3981-3991. (doi:10.1210/en.140.9.3981)

Hermans EJ, Henckens MJ, Joëls M \& Fernández G 2014 Dynamic adaptation of large-scale brain networks in response to acute stressors. Trends in Neurosciences 37 304-314. (doi:10.1016/j.tins.2014.03.006)

Herrero AI, Sandi C \& Venero C 2006 Individual differences in anxiety trait are related to spatial learning abilities and hippocampal expression of mineralocorticoid receptors. Neurobiology of Learning and Memory 86 150-159. (doi:10.1016/j.nlm.2006.02.001)

Hesen W, Karst H, Meijer O, Cole TJ, Schmid W, de Kloet ER, Schütz G \& Joëls M 1996 Hippocampal cell responses in mice with a targeted glucocorticoid receptor gene disruption. Journal of Neuroscience $\mathbf{1 6}$ 6766-6774

Ikeda M, Hojo Y, Komatsuzaki Y, Okamoto M, Kato A, Takeda T \& Kawato S 2015 Hippocampal spine changes across the sleep-wake cycle: corticosterone and kinases. Journal of Endocrinology 226 M13-M27. (doi:10.1530/JOE-15-0078)

Jaisser F \& Farman N 2016 Emerging roles of the mineralocorticoid receptor in pathology: toward new paradigms in clinical pharmacology. Pharmacological Reviews 68 49-75. (doi:10.1124/pr.115.011106)

Joëls M 2006 Corticosteroid effects in the brain: U-shape it. Trends in Pharmacological Sciences 27 244-250. (doi:10.1016/j. tips.2006.03.007)

Joëls M 2007 Role of corticosteroid hormones in the dentate gyrus. Progress in Brain Research 163 355-370. (doi.org/10.1016/s0079. 6123(07)63021-0)

Joëls M \& de Kloet ER 1990 Mineralocorticoid receptor-mediated changes in membrane properties of rat CA1 pyramidal neurons in vitro. PNAS 87 4495-4498. (doi:10.1073/pnas.87.12.4495)

Joëls M \& De Kloet ER 1992 Control of neuronal excitability by corticosteroid hormones. Trends in Neurosciences 15 25-30. (doi:10.1016/0166-2236(92)90345-9)

Joëls M \& de Kloet ER 1994 Mineralocorticoid and glucocorticoid receptors in the brain. Implications for ion permeability and transmitter systems. Progress in Neurobiology 43 1-36.

Joëls M, Hesen W \& de Kloet ER 1991 Mineralocorticoid hormones suppress serotonin-induced hyperpolarization of rat hippocampal CA1 neurons. Journal of Neuroscience 11 2288-2294.

Joëls M, Karst H, DeRijk R \& de Kloet ER 2008 The coming out of the brain mineralocorticoid receptor. Trends in Neurosciences 31 1-7. (doi:10.1016/j.tins.2007.10.005)

Joëls M, Sarabdjitsingh RA \& Karst H 2012 Unraveling the time domains of corticosteroid hormone influences on brain activity: rapid, slow, and chronic modes. Pharmacological Reviews 64 901-938. (doi:10.1124/pr.112.005892)

Kanatsou S, Fearey BC, Kuil LE, Lucassen PJ, Harris AP, Seckl JR, Krugers HJ \& Joëls M 2015 Overexpression of mineralocorticoid receptors partially prevents chronic stress-induced reductions in hippocampal memory and structural plasticity. PLOS ONE 10 e0145706. (doi:10.1371/journal.pone.0145706)

Karssen AM, Meijer OC, van der Sandt IC, Lucassen PJ, de Lange EC, de Boer AG \& de Kloet ER 2001 Multidrug resistance P-glycoprotein hampers the access of cortisol but not of corticosterone to mouse and human brain. Endocrinology 142 2686-2694. (doi:10.1210/ endo.142.6.8213) 
Karssen AM, Meijer OC, Berry A, Sanjuan Piñol R \& de Kloet ER 2005 Low doses of dexamethasone can produce a hypocorticosteroid state in the brain. Endocrinology 146 5587-5595. (doi:10.1210/en.2005-0501)

Karst H \& Joëls M 2016 Severe stress hormone conditions cause an extended window of excitability in the mouse basolateral amygdala. Neuropharmacology 110 175-180. (doi:10.1016/j. neuropharm.2016.07.027)

Karst H, Karten YJ, Reichardt HM, de Kloet ER, Schütz G \& Joëls M 2000 Corticosteroid actions in hippocampus require DNA binding of glucocorticoid receptor homodimers. Nature Neuroscience 3 977-978. (doi:10.1038/79910)

Karst H, Berger S, Turiault M, Tronche F, Schutz G \& Joëls M 2005 Mineralocorticoid receptors are indispensable for nongenomic modulation of hippocampal glutamate transmission by corticosterone. PNAS 102 19204-19207. (doi:10.1073/ pnas.0507572102)

Karst H, Berger S, Erdmann G, Schütz G \& Joëls M 2010 Metaplasticity of amygdalar responses to the stress hormone corticosterone. PNAS $\mathbf{1 0 7}$ 14449-14454. (doi:10.1073/pnas.0914381107)

Khaksari M, Rashidy-Pour A \& Vafaei AA 2007 Central mineralocorticoid receptors are indispensable for corticosterone induced impairment of memory retrieval in rats. Neuroscience 149 729-738. (doi:10.1016/j. neuroscience.2007.08.016)

Klok MD, Alt SR, Irurzun Lafitte AJ, Turner JD, Lakke EA, Huitinga I, Muller CP, Zitman FG, de Kloet ER \& Derijk RH 2011 $a$ Decreased expression of mineralocorticoid receptor mRNA and its splice variants in postmortem brain regions of patients with major depressive disorder. Journal of Psychiatric Research 45 871-878. (doi:10.1016/j. jpsychires.2010.12.002)

Klok MD, Giltay EJ, Van der Does AJ, Geleijnse JM, Antypa N, Penninx BW, de Geus EJ, Willemsen G, Boomsma DI \& van Leeuwen $\mathrm{N}$, et al. $2011 \mathrm{~b}$ A common and functional mineralocorticoid receptor haplotype enhances optimism and protects against depression in females. Translational Psychiatry 1 e62. (doi:10.1038/ tp.2011.59)

Koneru B, Bathina CS, Cherry BH \& Mifflin SW 2014 Mineralocorticoid receptor in the NTS stimulates saline intake during fourth ventricular infusions of aldosterone. American Journal of Physiology: Regulatory, Integrative and Comparative Physiology 306 R61-R66. (doi:10.1152/ ajpregu.00434.2013)

Korte SM, de Boer SF, de Kloet ER \& Bohus B 1995 Anxiolyticlike effects of selective mineralocorticoid and glucocorticoid antagonists on fear-enhanced behavior in the elevated plusmaze. Psychoneuroendocrinology 20 385-394. (doi:10.1016/03064530(94)00069-7)

Krause EG \& Sakai RR 2007 Richter and sodium appetite: from adrenalectomy to molecular biology. Appetite 49 353-367. (doi:10.1016/j.appet.2007.01.015)

Krozowski ZS \& Funder JW 1983 Renal mineralocorticoid receptors and hippocampal corticosterone-binding species have identical intrinsic steroid specificity. PNAS 80 6056-6060. (doi:10.1073/ pnas.80.19.6056)

Kruk MR, Haller J, Meelis W \& de Kloet ER 2013 Mineralocorticoid receptor blockade during a rat's first violent encounter inhibits its subsequent propensity for violence. Behavioral Neuroscience 127 505-514. (doi:10.1037/a0033553)

Liston C \& Gan WB 2011 Glucocorticoids are critical regulators of dendritic spine development and plasticity in vivo. PNAS 108 16074-16079. (doi:10.1073/pnas.1110444108)

Liston C, Cichon JM, Jeanneteau F, Jia Z, Chao MV \& Gan WB 2013 Circadian glucocorticoid oscillations promote learning-dependent synapse formation and maintenance. Nature Neuroscience 16 698-670. (doi:10.1038/nn.3387)

Liu W, Wang J, Sauter NK \& Pearce D 1995 Steroid receptor heterodimerization demonstrated in vitro and in vivo. PNAS 92 12480-12484. (doi:10.1073/pnas.92.26.12480)
McEwen BS, Weiss JM \& Schwartz LS 1968 Selective retention of corticosterone by limbic structures in rat brain. Nature 220 911-912. (doi:10.1038/220911a0)

McEwen BS, de Kloet R \& Wallach G 1976 Interactions in vivo and in vitro of corticoids and progesterone with cell nuclei and soluble macromolecules from rat brain regions and pituitary. Brain Research 105 129-136. (doi:10.1016/0006-8993(76)90928-8)

McEwen BS, Gray JD \& Nasca C 2015 Redefining neuroendocrinology: stress, sex and cognitive and emotional regulation. 60 years of neuroendocrinology. Journal of Endocrinology 226 T67-T83. (doi:10.1530/JOE-15-0121)

Meijer OC \& de Kloet ER 2017 A refill for the brain mineralocorticoid receptor: the benefit of cortisol add-on to dexamethasone therapy. Endocrinology [in press]. (doi:10.1210/en.2016-1495)

Meijer OC, de Lange ECM, De Boer AG Breimer DD, Workel JO \& De Kloet ER 1998 Penetration of dexamethasone in brain glucocorticoid targets is enhanced in mdr1a P glycoprotein knockout mice. Endocrinology 139 1789-1793. (doi:10.1210/en.139.4.1789)

Mifsud KR \& Reul JM 2016 Acute stress enhances heterodimerization and binding of corticosteroid receptors at glucocorticoid target genes in the hippocampus. PNAS 113 11336-11341. (doi:10.1073/ pnas.1605246113)

Moguilewsky M \& Raynaud JP 1980 Evidence for a specific mineralocorticoid receptor in rat pituitary and brain. Journal of Steroid Biochemistry 12 309-314. (doi:10.1016/0022-4731(80)90285-X)

Nasca C, Bigio B, Zelli D, Nicoletti F \& McEwen BS 2015 Mind the gap: glucocorticoids modulate hippocampal glutamate tone underlying individual differences in stress susceptibility. Molecular Psychiatry 20 755-763. (doi:10.1038/mp.2014.96)

Oitzl MS \& de Kloet ER 1992 Selective corticosteroid antagonists modulate specific aspects of spatial orientation learning. Behavioral Neuroscience 106 62-71. (doi:10.1037/0735-7044.106.1.62)

Oitzl MS, Fluttert M \& de Kloet ER 1994 The effect of corticosterone on reactivity to spatial novelty is mediated by central mineralocorticosteroid receptors. European Journal of Neuroscience 6 1072-1079. (doi:10.1111/j.1460-9568.1994.tb00604.x)

Oitzl MS, van Haarst AD, Sutanto W \& de Kloet ER 1995 Corticosterone, brain mineralocorticoid receptors (MRs) and the activity of the hypothalamic-pituitary-adrenal (HPA) axis: the Lewis rat as an example of increased central MR capacity and a hyporesponsive HPA axis. Psychoneuroendocrinology 20 655-675. (doi:10.1016/03064530(95)00003-7)

Oitzl MS, Workel JO, Fluttert M, Frösch F \& De Kloet ER 2000 Maternal deprivation affects behaviour from youth to senescence: amplification of individual differences in spatial learning and memory in senescent Brown Norway rats. European Journal of Neuroscience 12 3771-3780. (doi:10.1046/j.1460-9568.2000.00231.x)

Oitzl MS, Reichardt HM, Joëls M \& De Kloet ER 2001 Point mutation in the mouse glucocorticoid receptor preventing DNA binding impairs spatial memory. PNAS 98 12790-12795. (doi:10.1073/ pnas.231313998)

Olijslagers JE, de Kloet ER, Elgersma Y, van Woerden GM, Joëls M \& Karst H 2008 Rapid changes in hippocampal CA1 pyramidal cell function via pre- as well as postsynaptic membrane mineralocorticoid receptors. European Journal of Neuroscience 27 2542-2550. (doi:10.1111/j.1460-9568.2008.06220.x)

Patel PD, Katz M, Karssen AM \& Lyons DM 2008 Stress-induced changes in corticosteroid receptor expression in primate hippocampus and prefrontal cortex. Psychoneuroendocrinology 33 360-367. (doi:10.1016/j.psyneuen.2007.12.003)

Plihal W, Krug R, Pietrowsky R, Fehm HL \& Born J 1996 Corticosteroid receptor mediated effects on mood in humans. Psychoneuroendocrinology 21 515-523. (doi:10.1016/S0306-4530(96)00011-X)

Polman JA, de Kloet ER \& Datson NA 2013 Two populations of glucocorticoid receptor-binding sites in the male rat hippocampal genome. Endocrinology 154 1832-1844. (doi:10.1210/en.2012-2187)

Published by Bioscientifica Ltd 
Rahmouni K, Barthelmebs M, Grima M, Imbs JL \& De Jong W 1999 Cardiovascular and renal effects of central administration of a mineralocorticoid receptor antagonist in conscious female rats. European Journal of Pharmacology 385 199-202. (doi:10.1016/S00142999(99)00705-0)

Rahmouni K, Barthelmebs M, Grima M, Imbs JL \& De Jong W 2001 Involvement of brain mineralocorticoid receptor in salt-enhanced hypertension in spontaneously hypertensive rats. Hypertension $\mathbf{3 8}$ 902-906. (doi:10.1161/hy1001.091781)

Ratka A, Sutanto W, Bloemers M \& De Kloet ER 1989 On the role of brain mineralocorticoid (type I) and glucocorticoid (type II) receptors in neuroendocrine regulation. Neuroendocrinology 50 117-123. (doi:10.1159/000125210)

Reul JM \& de Kloet ER 1985 Two receptor systems for corticosterone in rat brain: microdistribution and differential occupation. Endocrinology 117 2505-2511. (doi:10.1210/endo-117-6-2505)

Reul JM, van den Bosch FR \& de Kloet ER 1987 Differential response of type I and type II corticosteroid receptors to changes in plasma steroid level and circadian rhythmicity. Neuroendocrinology $\mathbf{4 5}$ 407-412. (doi:10.1159/000124766)

Reul JM, Pearce PT, Funder JW \& Krozowski ZS 1989 Type I and type II corticosteroid receptor gene expression in the rat: effect of adrenalectomy and dexamethasone administration. Molecular Endocrinology 3 1674-1680. (doi:10.1210/mend-3-10-1674)

Rhees RW, Abel JH Jr \& Haack DW 1972 Uptake of tritiated steroids in the brain of the duck (Anas platyrhynchos). An autoradiographic study. General and Comparative Endocrinology 18 292-300. (doi:10.1016/00166480(72)90214-6)

Rocha R \& Stier CT Jr 2001 Pathophysiological effects of aldosterone in cardiovascular tissues. Trends in Endocrinology and Metabolism 12 308-314. (doi:10.1016/S1043-2760(01)00432-5)

Roland BL, Krozowski ZS \& Funder JW 1995 Glucocorticoid receptor, mineralocorticoid receptors, 11 beta-hydroxysteroid dehydrogenase-1 and -2 expression in rat brain and kidney: in situ studies. Molecular and Cellular Endocrinology 111 R1-R7. (doi:10.1016/03037207(95)03559-P)

Rozeboom AM, Akil H \& Seasholtz AF 2007 Mineralocorticoid receptor overexpression in forebrain decreases anxiety-like behavior and alters the stress response in mice. PNAS 104 4688-4693. (doi:10.1073/ pnas.0606067104)

Sakai RR, Nicolaiidis S \& Epstein AN 1986 Salt appetite is suppressed by interference with angiotensin II and aldosterone. American Journal of Physiology 251 R762-R768.

Sakai RR, McEwen BS, Fluharty SJ \& Ma LY 2000 The amygdala: site of genomic and nongenomic arousal of aldosterone-induced sodium intake. Kidney International 57 1337-1345. (doi:10.1046/j.1523 1755.2000.00972.x)

Sandi C \& Rose SP 1994 Corticosteroid receptor antagonists are amnestic for passive avoidance learning in day-old chicks. European Journal of Neuroscience 6 1292-1297. (doi:10.1111/j.1460-9568.1994.tb00319.x)

Sandi C \& Touyarot K 2006 Mid-life stress and cognitive deficits during early aging in rats: individual differences and hippocampal correlates. Neurobiology of Aging 27 128-140. (doi:10.1016/j. neurobiolaging.2005.01.006)

Sarabdjitsingh RA, Jezequel J, Pasricha N, Mikasova L, Kerkhofs A, Karst H, Groc L \& Joëls M 2014 Ultradian corticosterone pulses balance glutamatergic transmission and synaptic plasticity. PNAS 111 14265-14270. (doi:10.1073/pnas.1411216111)

Schwabe L, Schachinger H, de Kloet ER \& Oitzl MS 2010 Corticosteroids operate as a switch between memory systems. Journal of Cognitive Neuroscience 22 1362-1372. (doi:10.1162/jocn.2009.21278)

Schwabe L, Joëls M, Roozendaal B, Wolf OT \& Oitzl MS 2012 Stress effects on memory: an update and integration. Neuroscience and Biobehavioral Reviews 36 1740-1749. (doi:10.1016/j.neubiorev.2011.07.002)

Schwabe L, Tegenthoff M, Höffken O \& Wolf OT 2013 Mineralocorticoid receptor blockade prevents stress-induced modulation of multiple memory systems in the human brain. Biological Psychiatry $\mathbf{7 4}$ 801-808. (doi:10.1016/j.biopsych.2013.06.001)

Seckl JR \& Fink G 1992 Antidepressants increase glucocorticoid and mineralocorticoid receptor mRNA expression in rat hippocampus in vivo. Neuroendocrinology 55 621-626. (doi:10.1159/000126180)

Selye H 1952 The Story of the Adaptation Syndrome. Montreal, Canada: Acta, Inc.

Sousa N 2016 The dynamics of the stress neuromatrix. Molecular Psychiatry 21 302-312. (doi:10.1038/mp.2015.196)

Sutanto W \& De Kloet ER 1987 Species-specificity of corticosteroid receptors in hamster and rat brains. Endocrinology 121 1405-1411. (doi:10.1210/endo-121-4-1405)

Sutanto W, Oitzl MS, Rots NY, Schöbitz B, Van den Berg DT, Van Dijken HH, Mos J, Cools AR, Tilders FJ, Koolhaas JM, et al. 1992 Corticosteroid receptor plasticity in the central nervous system of various rat models. Endocrine Regulations 26 111-118.

Ter Horst JP, Kentrop J, Arp M, Hubens CJ, de Kloet ER \& Oitzl MS 2013 Spatial learning of female mice: a role of the mineralocorticoid receptor during stress and the estrous cycle. Frontiers in Behavioral Neuroscience 7 56. (doi:10.3389/fnbeh.2013.00056)

Trapp T \& Holsboer F 1996 Heterodimerization between mineralocorticoid and glucocorticoid receptors increases the functional diversity of corticosteroid action. Trends in Pharmacological Sciences 17 145-149. (doi:10.1016/0165-6147(96)81590-2)

van den Berg DT, de Kloet ER, van Dijken HH \& de Jong W 1990 Differential central effects of mineralocorticoid and glucocorticoid agonists and antagonists on blood pressure. Endocrinology 126 118-124. (doi:10.1210/endo-126-1-118)

van den Berg DT, de Jong W \& de Kloet ER 1994 Mineralocorticoid antagonist inhibits stress-induced blood pressure response after repeated daily warming. American Journal of Physiology 267 E921-E926.

Van Eekelen JA, Jiang W, De Kloet ER \& Bohn MC 1988 Distribution of the mineralocorticoid and the glucocorticoid receptor mRNAs in the rat hippocampus. Journal of Neuroscience Research 21 88-94. (doi:10.1002/jnr.490210113)

van Eekelen JA, Oitzl MS \& De Kloet ER 1995 Adrenocortical hyporesponsiveness and glucocorticoid feedback resistance in old male brown Norway rats. Journals of Gerontology Series A: Biological Sciences and Medical Sciences 50 B83-B89. (doi:10.1093/ gerona/50a.2.b83)

van Gemert NG, Carvalho DM, Karst H, van der Laan S, Zhang M, Meijer OC, Hell JW \& Joëls M 2009 Dissociation between rat hippocampal CA1 and dentate gyrus cells in their response to corticosterone: effects on calcium channel protein and current Endocrinology 150 4615-4624. (doi:10.1210/en.2009-0525)

van Haarst AD, Oitzl MS \& de Kloet ER 1997 Facilitation of feedback inhibition through blockade of glucocorticoid receptors in the hippocampus. Neurochemical Research 22 1323-1328. (doi:10.102 3/A:1022010904600)

van Leeuwen N, Caprio M, Blaya C, Fumeron F, Sartorato P, Ronconi V, Giacchetti G, Mantero F, Fernandes-Rosa FL \& Simian C 2010 The functional c.-2G >C variant of the mineralocorticoid receptor modulates blood pressure, renin, and aldosterone levels. Hypertension 56 995-1002. (doi:10.1161/ HYPERTENSIONAHA.110.155630)

van Leeuwen N, Bellingrath S, de Kloet ER, Zitman FG, DeRijk RH, Kudielka BM \& Wüst S 2011 Human mineralocorticoid receptor (MR) gene haplotypes modulate MR expression and transactivation: implication for the stress response. Psychoneuroendocrinology 36 699-709. (doi:10.1016/j.psyneuen.2010.10.003)

van Steensel B, van Binnendijk EP, Hornsby CD, van der Voort HT, Krozowski ZS, de Kloet ER \& van Driel R 1996 Partial colocalization of glucocorticoid and mineralocorticoid receptors in discrete compartments in nuclei of rat hippocampus neurons. Journal of Cell Science 109 787-92. 
van Weert LTCM, Buurstede JC, Mahfouz A, Braakhuis PSM, Polman JE, Sips HCM, Roozendaal B, Balog J, de Kloet ER, Datson NA, et al. 2017 NeuroD factors discriminate mineralocorticoid from glucocorticoid receptor DNA binding in the male rat brain. Endocrinology [in press]. (doi:10.1210/en.2016-1422)

Veenema AH, Meijer OC, de Kloet ER, Koolhaas JM \& Bohus B 2003 Differences in basal and stress-induced HPA regulation of wild house mice selected for high and low aggression. Hormones and Behavior $\mathbf{4 3}$ 197-204. (doi:10.1016/S0018-506X(02)00013-2)

Veldhuis HD, Van Koppen C, Van Ittersum M \& De Kloet ER 1982 Specificity of the adrenal steroid receptor system in the rat hippocampus. Endocrinology 110 2044-2051. (doi:10.1210/endo-110-6-2044)

Vinkers CH, Joëls M, Milaneschi Y, Gerritsen L, Kahn RS, Penninx BW \& Boks MP 2015 Mineralocorticoid receptor haplotypes sexdependently moderate depression susceptibility following childhood maltreatment. Psychoneuroendocrinology 54 90-102. (doi:10.1016/j. psyneuen.2015.01.018)

Vogel S, Klumpers F, Kroes MC, Oplaat KT, Krugers HJ, Oitzl MS, Joëls M \& Fernández G 2015a A stress-induced shift from trace to delay conditioning depends on the mineralocorticoid receptor. Biological Psychiatry 78 830-839. (doi:10.1016/j.biopsych.2015.02.014)

Vogel S, Klumpers F, Krugers HJ, Fang Z, Oplaat KT, Oitzl MS, Joëls M \& Fernández G $2015 b$ Blocking the mineralocorticoid receptor in humans prevents the stress-induced enhancement of centromedial amygdala connectivity with the dorsal striatum. Neuropsychopharmacology 40 947-956. (doi:10.1038/npp.2014.271)

Vogel S, Fernández G, Joëls M \& Schwabe L 2016a Cognitive adaptation under stress: a case for the mineralocorticoid receptor. Trends in Cognitive Sciences 20 192-203. (doi:10.1016/j.tics.2015.12.003)

Vogel S, Klumpers F, Schröder TN, Oplaat KT, Krugers HJ, Oitzl MS, Joëls M, Doeller CF \& Fernández G 2016b Stress induces a shift towards striatum-dependent stimulus-response learning via the mineralocorticoid receptor. Neuropsychopharmacology [in press]. (doi:10.1038/npp.2016.262)

Warris LT, van den Heuvel-Eibrink MM, Aarsen FK, Pluijm SM, Bierings MB, van den Bos C, Zwaan CM, Thygesen $\mathrm{HH}$, Tissing WJ \& Veening MA, et al. 2016 Hydrocortisone as an intervention for dexamethasone-induced adverse effects in pediatric patients with acute lymphoblastic leukemia: results of a double-blind, randomized controlled trial. Journal of Clinical Oncology 34 2287-2293. (doi:10.1200/ JCO.2015.66.0761)

Wang HW, Huang BS, Chen A, Ahmad M, White RA \& Leenen FH 2016 Role of brain aldosterone and mineralocorticoid receptors in aldosterone-salt hypertension in rats. Neuroscience 314 90-105. (doi:10.1016/j.neuroscience.2015.11.055)

Wong EY \& Herbert J 2005 Roles of mineralocorticoid and glucocorticoid receptors in the regulation of progenitor proliferation in the adult hippocampus. European Journal of Neuroscience 22 785-792. (doi:10.1111/j.1460-9568.2005.04277.x)

Yongue BG \& Roy EJ 1987 Endogenous aldosterone and corticosterone in brain cell nuclei of adrenal-intact rats: regional distribution and effects of physiological variations in serum steroids. Brain Research 436 49-61. (doi:10.1016/0006-8993(87)91555-1)

Young MJ, Morgan J, Brolin K, Fuller PJ \& Funder JW 2010 Activation of mineralocorticoid receptors by exogenous glucocorticoids and the development of cardiovascular inflammatory responses in adrenalectomized rats. Endocrinology 151 2622-2628. (doi:10.1210/ en.2009-1476)

Zalachoras I, Houtman R \& Meijer OC 2013 Understanding stresseffects in the brain via transcriptional signal transduction pathways. Neuroscience 242 97-109. (doi:10.1016/j.neuroscience.2013.03.038)

Received in final form 6 February 2017

Accepted 20 February 2017
() 2017 Society for Endocrinology Printed in Great Britain 